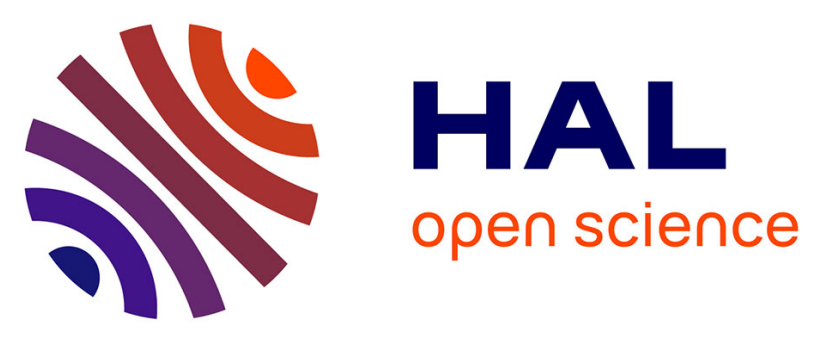

\title{
Home conservation strategies for tomato (Solanum lycopersicum): Storage temperature vs. duration - Is there a compromise for better aroma preservation?
}

Christian Ginies, Barbara Gouble, Sylvie Bureau, Mathilde Causse, Catherine C. Renard

\section{To cite this version:}

Christian Ginies, Barbara Gouble, Sylvie Bureau, Mathilde Causse, Catherine C. Renard. Home conservation strategies for tomato (Solanum lycopersicum): Storage temperature vs. duration - Is there a compromise for better aroma preservation?. Food Chemistry, 2013, 139 (1-4), pp.825-836. 10.1016/j.foodchem.2013.01.038 . hal-01328646

\section{HAL Id: hal-01328646 https://hal.science/hal-01328646}

Submitted on 28 May 2020

HAL is a multi-disciplinary open access archive for the deposit and dissemination of scientific research documents, whether they are published or not. The documents may come from teaching and research institutions in France or abroad, or from public or private research centers.
L'archive ouverte pluridisciplinaire HAL, est destinée au dépôt et à la diffusion de documents scientifiques de niveau recherche, publiés ou non, émanant des établissements d'enseignement et de recherche français ou étrangers, des laboratoires publics ou privés. 


\section{Accepted Manuscript}

Home conservation strategies for tomato (Solanum lycopersicum): storage temperature $v s$. duration - is there a compromise for better aroma preservation?

Catherine M.G.C. Renard, Christian Ginies, Barbara Gouble, Sylvie Bureau, Mathilde Causse

PII: S0308-8146(13)00062-9

DOI: http://dx.doi.org/10.1016/j.foodchem.2013.01.038

Reference: FOCH 13585

To appear in: Food Chemistry

Received Date: 17 August 2012

Revised Date: 19 November 2012

Accepted Date: 14 January 2013

Please cite this article as: Renard, C.M.G., Ginies, C., Gouble, B., Bureau, S., Causse, M., Home conservation strategies for tomato (Solanum lycopersicum): storage temperature vs. duration - is there a compromise for better aroma preservation?, Food Chemistry (2013), doi: http://dx.doi.org/10.1016/j.foodchem.2013.01.038

This is a PDF file of an unedited manuscript that has been accepted for publication. As a service to our customers we are providing this early version of the manuscript. The manuscript will undergo copyediting, typesetting, and review of the resulting proof before it is published in its final form. Please note that during the production process errors may be discovered which could affect the content, and all legal disclaimers that apply to the journal pertain. 


\section{Home conservation strategies for tomato (Solanum}

\section{2 lycopersicum): storage temperature vs. duration - is there a}

\section{3 compromise for better aroma preservation?}

4

5 Catherine M.G.C. Renard ${ }^{1 *}$, Christian Ginies ${ }^{1}$, Barbara Gouble ${ }^{1}$, Sylvie Bureau ${ }^{1} \&$ Mathilde

6 Causse $^{2}$

7

81 INRA, UMR408 Sécurité et Qualité des Produits d'Origine Végétale, F-84000 Avignon,

9 France

101 Université d'Avignon et des Pays de Vaucluse, UMR408 Sécurité et Qualité des Produits

11 d'Origine Végétale, F-84000 Avignon, France

12 INRA, Unité de Génétique et d'Amélioration des Fruits et Légumes, F-84143 Montfavet,

13 France 


\section{ABSTRACT}

15

16 Expression of dissatisfaction with tomato aroma prompted us to lead this study on the impact

17 of domestic storage conditions on volatile compounds.

18 Two storage modalities $\left(20^{\circ} \mathrm{C}\right.$ and $\left.4{ }^{\circ} \mathrm{C}\right)$ and two cultivars (Levovil and LCx) were used.

19 Volatile compounds were analyzed by gas chromatography-mass spectrometry detection after accelerated solvent extraction. Physical characteristics, lipoxygenase activity, hydroperoxide

21 lyase activity; linoleic acid and linolenic acid were monitored.

22 Storing tomatoes at $4{ }^{\circ} \mathrm{C}$ induced a drastic loss in volatiles, whatever their biosynthetic origin.

23 After 30 days at $4{ }^{\circ} \mathrm{C}$, the concentration of volatiles had decreased by $66 \%$. Reconditioning

24 for $24 \mathrm{~h}$ at $20^{\circ} \mathrm{C}$ was able to recover some aroma production after up to 6 days storage at 4

${ }^{\circ} \mathrm{C}$. Volatile degradation products arising from carotenoids and amino acids increased when tomatoes were kept at $20^{\circ} \mathrm{C}$, while lipid degradation products did not vary.

27 Storing tomatoes at fridge temperature, even for short durations, was detrimental for their

28 aroma. This should be taken into account to formulate practical advice for consumers.

30 Keywords

31 Storage, volatiles, lipoxygenase, GC-MS, accelerated solvent extraction

32 
34 In recent years, consumption of fresh tomatoes by French consumers has stagnated, and market research points to dissatisfaction with the sensory quality of fresh tomatoes on sale.

This motivated the Agence Nationale de la Recherche [French national research agency] project "QualitomFil", which aims to find ways to maintain a high quality supply chain from farm to fork. This study was led under the QualitomFil program. Our hypothesis is that inadequate storage conditions at the consumer's home contributes to the perceived flavour loss. Little is known about the fate of tomatoes at the last link of this chain - the consumer. The consumer has two main possibilities for tomato storage: at room temperature or in the refrigerator at around $4{ }^{\circ} \mathrm{C}$. The general physico-chemical characteristics of ripe (light red or red) tomato, such as soluble solids and acidity, are little modified during home storage (Auerswald, Peters, Brückner, Krumbein, \& Kuchenbuch, 1999; de Leon-Sanchez, PelayoZaldivar, Rivera-Cabrera, Ponce-Valadez, Avila-Alejandre, Fernandez, et al., 2009; Maul, Sargent, Sims, Baldwin, Balaban, \& Huber, 2000). However, this is not the case with volatile compounds, and one of the key sensory parameters for tomato frequently mentioned in consumer complaints is loss of its characteristic aroma. This motivated our investigation of the fate of tomato volatiles during storage in domestic conditions.

51 Data, mostly on unripe tomatoes, indicates that low temperature affects volatiles production.

52 As chilling injury is a well-known risk for this fruit, temperatures $>10{ }^{\circ} \mathrm{C}$ are recommended

53 and relatively few studies can be found dealing with the impact of low temperatures on taste

54 and flavour volatiles. Stern, Buttery, Teranishi, Ling, Scott \& Cantwell (1994) stored tomatoes harvested mature green, breaker (defined as the maturity stage when the red colour starts becoming visible at the tip of the tomato) to red-ripe at temperatures from $5{ }^{\circ} \mathrm{C}$ to 20 
57

${ }^{\circ} \mathrm{C}$. Red-ripe tomato held at $5{ }^{\circ} \mathrm{C}$ had significantly less volatiles than when stored at 20,15 or $10{ }^{\circ} \mathrm{C}$ for the same duration (6 days). Stern et al. (1994) further verified lack of volatile development when unripe tomatoes were stored at chilling conditions, and highlighted that final ripening temperature was a paramount determinant of ultimate odour intensity. Maul et al. (2000) reported that light-red tomatoes stored at $5{ }^{\circ} \mathrm{C}$ are rated by a trained panel as significantly lower for ripe aroma, sweetness and tomato flavour and significantly higher in sourness than when stored at $20^{\circ} \mathrm{C}$ for the same duration. The concentrations of sugars were actually higher at $5{ }^{\circ} \mathrm{C}$ than at $20{ }^{\circ} \mathrm{C}$ while $\mathrm{pH}$ and titratable acidity were not statistically different. The authors also reported significant losses in hexanal, 2+3-methylbutanol, (E)-2heptenal, and 2-isobutylthiazole for all fruits stored below $20^{\circ} \mathrm{C}$.

De Leon-Sanchez et al. (2009) recently compared sensory analysis, volatiles and alcohol dehydrogenase activity in tomatoes harvested at the light red stage and stored either at $10{ }^{\circ} \mathrm{C}$ or $20^{\circ} \mathrm{C}$. The first modifications detected at low temperature were a decrease in hexanol and an increase in 3-methylbutanal, linked to a modification of the aldehyde/alcohol balance, which the authors explained by a decrease in alcohol dehydrogenase activity during lowtemperature storage. In the sensory evaluation, little difference was reported for storage at 20 ${ }^{\circ} \mathrm{C}$ (up to 14 days), while at $10{ }^{\circ} \mathrm{C}$ the assessors detected an increase in "solvent-humidity" and a decrease in "lemon tea" descriptors.

Tomato aroma during eating has two main sources: the pre-existing volatiles, and a series of major volatile compounds known as lipoxygenase-derived products (or LOX products) (Baysal \& Demirdoven, 2007; Riley \& Thompson, 1998; Robinson, Wu, Domoney, \& Casey, 1995). These volatile compounds result from the oxidative degradation of linoleic and linolenic acids that occurs when the internal structure of the cells is broken down. This loss of cellular structure can be provoked by mastication or grinding (Riley \& Thompson, 1998; Xu 
$82 \&$ Barringer, 2010). As a result, the chloroplastic enzymes (lipoxygenase (LOX) and

83 hydroperoxidelyase (HPL)) come into contact with their cytosolic substrate. LOX products

84 are therefore produced during mastication (Linforth, Savary, Pattenden, \& Taylor, 1994).

85

86 The aim was to investigate the impact of storage in domestic conditions $\left(20^{\circ} \mathrm{C}\right.$ and $\left.4{ }^{\circ} \mathrm{C}\right)$ on

87 tomato volatiles, and to assess means to obviate aroma loss. Volatiles from two varieties of

88 tomatoes known to differ in intensity of flavour were analyzed at the two storage

89 temperatures. This study also determined the time-course evolution of potential drivers of

90 generation "in-mouth" of LOX products, i.e. LOX and hydroperoxide lyase activities and

91 concentration of linoleic and linolenic fatty acids substrates.

92 


\subsection{Plant material}

96

97

98

Plants were grown in a heated glasshouse in Avignon (southeast France) during spring 2008.

Fruits were harvested at the red-ripe stage on Levovil, characterized by its large fruits and pharmaceutical sensory attributes, and $\mathrm{LCx}$, an introgressed line carrying five chromosome regions from the Cervil cherry tomato identified as bearing the quantitative trait loci for quality traits, notably tomato aroma intensity (Chaib, Lecomte, Buret, \& Causse, 2006) in the Levovil background. In order to eliminate bias linked to maturation patterns, both tomatoes were harvested at the red-ripe stage. To ensure homogeneous maturity and avoid the presence of overripe tomatoes, plants were first unloaded of all their red fruits and 3 days later the fruits which had ripened from orange to red were harvested. Each line was represented by 18 plants.

\subsection{Chemicals}

All standard volatile compounds, linolenic acid, yeast alcohol dehydrogenase, soybean type IB lipoxidase and NADH were purchased from Sigma Aldrich (St Louis, MO). Solvents were from Carlo Erba Reagents (Val de Reuil, France). Hydromatrix ${ }^{\mathrm{TM}}$ (diatomaceous earth) was from Agilent Technologies (Les Ulys, France). $\mathrm{BF}_{3} /$ Methanol was purchased from VWR international (Fontenay-sous-Bois, France).

\subsection{Tomato storage}

At harvest, tomatoes were divided into 12 modalities: fresh; storage at $20^{\circ} \mathrm{C}$ for 1,3 or 6 days; storage at $4{ }^{\circ} \mathrm{C}$ for $1,6,15$ and 30 days; same, followed by $24 \mathrm{~h}$ reconditioning at $20^{\circ} \mathrm{C}$. 
117 Each modality comprised 3 replicates of 5 fruits. All storage was carried out in temperature-

118 controlled, air-circulated chambers. To eliminate effects of temperature on enzyme activity

119 during the aroma extraction procedure, tomatoes stored at $4{ }^{\circ} \mathrm{C}$ were brought back to $20{ }^{\circ} \mathrm{C}$

120 prior to analysis by incubation $(30 \mathrm{~min})$ in water at $20^{\circ} \mathrm{C}$.

121 Tomatoes were characterized at harvest and after storage for weight, firmness and colour.

122 Fruit colour was measured in the CIE $\mathrm{L} * \mathrm{C} * \mathrm{~h} *$ (lightness, chroma and hue) colour space using

123 a CM-1000R-series Minolta chromameter (Minolta, Ramsey, NJ).

124 Fruit texture was measured with a multi-purpose texturometer (Texture analyzer TAplus:

125 Ametek, Lloyd Instruments Ltd., Fareham, UK). This apparatus registered force/deformation

126 curves by measuring the reaction force in response to an increasing mechanical constraint

127 applied to the fruit by a $5 \mathrm{~cm}$ flat disc and a $250 \mathrm{~N}$ load cell. Probe speed was $20 \mathrm{~mm} \cdot \mathrm{min}^{-1}$.

128 Fruit firmness (F) was the force necessary to obtain a deformation corresponding to $3 \%$ of

129 the fruit diameter.

130

2.4 Accelerated solvent extraction (ASE)

132 Five tomatoes were ground for $1 \mathrm{~min}$ in a blender (Waring-Nova, Grosseron, St Herblain,

133 France), and approximately $15 \mathrm{~g}$ of juice was transferred to a beaker. After 2 minutes, $15 \mathrm{~g}$ of

134 Hydromatrix ${ }^{\mathrm{TM}}$ and $16 \mu \mathrm{g}$ of 4-nonanol (internal standard) were mixed with the tomato juice

135 to obtain a homogeneous powder while inactivating enzymes. The powder was rapidly

136 transferred to a $33 \mathrm{ml}$ pressurized extraction cell for immediate extraction. The extractor was

137 an ASE 200 system (Dionex, Sunnyvale, CA). Extraction conditions were: solvent

138 dichloromethane, $100 \mathrm{bar}, 40{ }^{\circ} \mathrm{C}, 5 \mathrm{~min}$ preheating then $5 \mathrm{~min}$ static incubation. The extract

139 was concentrated to $1 \mathrm{ml}$ by distillation under vacuum (300 Pa, using a Multivapor R12,

140 Buchi, Rungis, France) prior to gas chromatography. This step showed no significant loss in 
141 volatile compounds compared to distillation at ambient pressure (Trad, Ginies, Gaaliche,

142 Renard, \& Mars, 2012).

143

144

2.5 GC-MS

145 Volatile samples ( $2 \mu \mathrm{l})$ were injected into a GC-MS system (QP2010; Shimadzu, Kyoto,

146 Japan) equipped with a UB Wax capillary column [30 m, $0.32 \mathrm{~mm}$ i.d., $0.5 \mu \mathrm{m}$ film thickness]

147 (Interchim, Montluçon, France) as described in Birtic, Ginies, Causse, Page \& Renard (2009).

148 A total of 44 volatile compounds were detected (Table 1).

149

150 Detection of LOX volatile oxidation products used a CPSIL 5 CB capillary column [30 m,

151

152

153

154

155

156

157

158

159

160 Fatty acids were analyzed by GC-MS after transesterification to fatty acid methyl esters

161 (FAME). Total lipid extract was based on Schäfer (1998), with modifications. $500 \mathrm{mg}$ of

162 freeze-dried tomato (without seed) was homogenized with $10 \mathrm{~g}$ of Fontainebleau sand and

163 transferred into a $11 \mathrm{ml}$ pressurized extraction cell, and then $0.25 \mathrm{mg}$ of nonadecanoic acid

164 (internal standard) was introduced. The extractor was an ASE 200 system (Dionex, 
165 Sunnyvale, $\mathrm{CA})$, with $\mathrm{CHCl}_{3} / \mathrm{Methanol}\left(2 / 1\right.$, v/v) as solvent, 100 bars, $120^{\circ} \mathrm{C}, 5 \mathrm{~min}$

166 preheating then 5 min static incubation, flushed $50 \%$ and one cycle.

167 A $1 \mathrm{ml}$ aliquot of extract was transesterified by adding $1 \mathrm{ml}$ of $\mathrm{BF}_{3} /$ methanol (10 \%) then

168 incubated at $85^{\circ} \mathrm{C}$ for $1 \mathrm{~h}$. After cooling, $2 \mathrm{ml}$ hexane and $2 \mathrm{ml}$ of $\mathrm{HCO}_{3}{ }^{-} 0.2 \mathrm{~mol} / \mathrm{L}$ were

169 added. The tube was vortexed and the organic phase was dried.

$1701 \mu \mathrm{L}$ of FAME was injected on the UBWAX capillary column $[30 \mathrm{~m}, 0.25 \mathrm{~mm}$ i.d., $0.5 \mu \mathrm{m}$

171 film thickness] (Interchim, Montluçon, France). The injection port was operated in splitless

172 mode for the first $30 \mathrm{~s}$, after which the carrier gas (He) velocity was kept a constant $35 \mathrm{~cm} \cdot \mathrm{s}^{-1}$.

173 The initial oven temperature of $50{ }^{\circ} \mathrm{C}$ was held for $1 \mathrm{~min}$ and then ramped up at $20^{\circ} \mathrm{C}$ per min

174 to $200{ }^{\circ} \mathrm{C}$ then at $3{ }^{\circ} \mathrm{C}$ per min to $230{ }^{\circ} \mathrm{C}$. This final temperature was held for $15 \mathrm{~min}$. The

175 mass spectrometer was operated in electron ionization mode at $70 \mathrm{eV}$ with continuous scans

176 (every $0.5 \mathrm{~s}$ ) from mass-to-charge ratio $(\mathrm{m} / \mathrm{z}) 50$ to 360.

177 Fatty acid levels were expressed in milligrams of methyl nonadecanoate equivalent.

178

179

\subsection{Enzyme activities}

180 Enzyme extraction was based on Riley, Willemot, \& Thompson (1996) and Rodrigo, Jolie,

181 Van Loey, \& Hendrickx (2007). Proteins were extracted by grinding $50 \mathrm{~g}$ of tomato pericarp

182 with $50 \mathrm{~g}$ of cold $0.2 \mathrm{~mol} / \mathrm{L}$ sodium phosphate buffer $\mathrm{pH} 6.5$ containing $2 \mathrm{ml} / \mathrm{L}$ of Triton $\mathrm{X}$ -

183100 , followed by centrifugation at $10000 \mathrm{~g}$ for $10 \mathrm{~min}$ at $4{ }^{\circ} \mathrm{C}$. Protein concentration was

184 measured by the Bradford method (Bradford, 1976).

185

186 LOX activity was measured by increase in absorbance at $234 \mathrm{~nm}$ corresponding to the

187 generation of conjugated double bonds in linoleic acid (Surrey, 1964).The supernatant (40

$188 \mu \mathrm{L}$ ) was added to $2 \mathrm{ml}$ of phosphate buffer $\mathrm{pH} 6$ and $40 \mu \mathrm{l}$ of a linoleic acid solution

189 (dissolved at $6 \mu \mathrm{g} / \mathrm{ml}$ in $\mathrm{NaOH} 24 \mathrm{mmol} / \mathrm{L}$ plus Tween $2010 \mathrm{mg} / \mathrm{l}$ ). Absorbance at $234 \mathrm{~nm}$ 
190

was monitored for $5 \mathrm{~min}$. Activity was expressed as absorbance per min per $\mathrm{ml}$ of tomato

191 extract.

192 HPL activity was measured using the NADH-coupled enzyme assay of Vick (1991) as the

193 decrease in absorbance at $340 \mathrm{~nm}$ on oxidation of $\mathrm{NaDH}$, a co-factor for alcohol

194 dehydrogenase. The hydroperoxylinolenic acid substrate for HPL was prepared according to Vick (1991). The assay mixture contained $200 \mu \mathrm{l}$ of supernatant, $500 \mu \mathrm{L}$ of substrate, $150 \mu \mathrm{L}$ of 150 units yeast alcohol dehydrogenase solution, and $50 \mu \mathrm{l}$ of $10 \mathrm{mmol} / \mathrm{L} \mathrm{NADH}$. A blank was performed with the assay mixture to check NADH stability during analysis.

\subsection{Statistical analysis}

Results are presented as mean values, and the reproducibility of the results is expressed as a pooled standard deviation. Pooled standard deviations were calculated for each series of replicates using the sum of individual variances weighted by the individual degrees of freedom (Box, Hunter, \& Hunter, 1978). PCA was carried out using ExcelStat (Microsoft, Redmond, WA). 
205

206

207

208

209

210

211

212

213

214

215

216

217

218

219

220

221

222

223

224

225

226

227

228

\section{Results}

\subsection{Tomato characteristics}

The two tomato lines presented the expected general characteristics. In order to eliminate bias linked to maturation patterns, both tomatoes were harvested at the red-ripe stage. Levovil were much bigger than LCx (Table 2) and were also less firm. Firmness decreased during storage for both varieties. For $\mathrm{LCx}$, the decrease was delayed by storage at $4{ }^{\circ} \mathrm{C}$, while for Levovil temperature had no influence on loss of texture (Fig 1A and B). Both were picked fully red-ripe as visible from their high saturation values and hue angles close to $45^{\circ}$. No significant variations during storage were found for fruit weight, luminance or saturation (Table 2). Hue angle decreased significantly during storage at $20^{\circ} \mathrm{C}$ (but not at $4{ }^{\circ} \mathrm{C}$ ) for $\mathrm{LCx}$ (Fig. 1C) whereas it increased significantly for storage at $4{ }^{\circ} \mathrm{C}$ (but not $20^{\circ} \mathrm{C}$ ) for Levovil (Fig. 1D). The time-course evolution of physical characteristics during storage was conform to the expected behavior of tomatoes, with loss of texture and an increase in red colour (lycopene production) at $20^{\circ} \mathrm{C}$.

\subsection{Volatiles in the fresh tomatoes}

Total volatiles concentration was much higher overall in LCx than in Levovil (Fig. 2, Tables 3-5). Eugenol and 2-methoxyphenol were detected only in Levovil, and methyl salicylate was $>50$ times higher in Levovil than in LCx (Table 3). The difference in concentrations was also particularly clear for volatiles originating from phenylalanine and from sulfur-containing amino acids (Table 4). Benzylalcohol concentration was 22-fold higher, benzaldehyde 7-fold higher and 2-phenylethanol about 4-fold higher in LCx than in Levovil. All products identified as originating from sulfur-containing amino acids were 4-7-fold more concentrated 
229

230

231

232

233

234

235

236

237

238

239

240

241

242

243

244

245

246

247

248

249

250

251

252

253

in LCx than in Levovil. For products originating from leucine/isoleucine, 3-methyl-1-butanol was 4-fold higher in LCx whereas 2-isobutylthiazole was slightly higher in Levovil. Furaneol (from carbohydrates) was also present in higher concentrations in LCx.

Noticeable but lower differences were found for the lipid-derived volatiles (Table 5). The LOX (lipoxygenase) pathway is the origin of the C6 volatiles in tomatoes. The lipid-derived volatiles are formed from the breakdown of linoleic (C18:2) and linolenic acids (C18:3) that are cleaved by lipoxygenase to form $\mathrm{C} 13$ intermediates, themselves further modified by other enzymes in the LOX pathway, notably hydroperoxide lyase (HPL). Only (E)-2-hexenal was 7-fold more concentrated in LCx than in Levovil, while for all others the LCx/Levovil ratios were close to 2. Amounts of the linoleic and linolenic acid precursors as well as global LOX and HPL activities were similar between LCx and Levovil (Table 6).

There were only limited differences between the two lines in terms of products of carotenoid catabolism (Table 3), except farnesylacetone which was 3-fold higher in LCx.

\subsection{Time-course evolution of volatiles during storage}

\subsubsection{General}

During storage (Fig. 2), total volatiles increased at $20{ }^{\circ} \mathrm{C}$ and decreased markedly at $4{ }^{\circ} \mathrm{C}$ for both LCx and Levovil lines. Reconditioning at $20^{\circ} \mathrm{C}$ allowed some recovery of volatile production for LCx (though not at 30 days) but not for Levovil.

\subsubsection{Global characterization}

Principal Component Analysis (PCA) was carried out to obtain a general overview of the specific volatiles during storage. The original PCA was carried out using all individuals and volatiles; for readability, Fig. 3 shows the PCA carried out using averages of the three replicates and variables selected by keeping only one of the most highly-correlated variables. 
254 Similar patterns were obtained with the full and the simplified data set. As expected, LCx and

255 Levovil were clearly differentiated on the first plane of PCA (71\% of variance) (Fig. 3A).

256 LCx was in the same quadrant as most volatiles in the correlation circle (Fig. 3B), which can

257 be related to its generally higher production of volatiles. The Levovil/LCx separation along

258 principal component 2 also corresponded to the position of the phenylpropanoid derivatives

259 on the correlation circle. Methylsalicylate, (eugenol and 2-methoxyphenol are correlated with

260 methylsalicylate but not represented on the figure) present in Levovil but not in LCx, and 4-

261 vinyl-2-methoxyphenol, almost exclusively present in LCx (Table 3), were opposed.

262 Evolutions of sample projections during storage were very different depending on

263 temperature, but followed similar trends in the two lines (Fig 3A). The evolution observed for

264 storage at $4{ }^{\circ} \mathrm{C}$ was negatively correlated with all volatiles while the evolution for storage at

$26520^{\circ} \mathrm{C}$ was correlated with a majority of detected volatiles, which is in agreement with the

266 global evolution described in Fig. 2. Levovil samples moved mostly along axis 2 (up with

267 storage at $20^{\circ} \mathrm{C}$, down with storage at $4{ }^{\circ} \mathrm{C}$ ) while for $\mathrm{LCx}$ the coordinates along axes 1 and 2

268 were affected to the same extent (up and to the right at $20^{\circ} \mathrm{C}$, down and to the left at $4{ }^{\circ} \mathrm{C}$ ).

269 The effects of reconditioning at $20{ }^{\circ} \mathrm{C}$ for $24 \mathrm{~h}$ (samples in italics) were most marked for

270 samples kept for shorter storage durations. For tomatoes that had only been stored $24 \mathrm{~h}$ at 4

$271{ }^{\circ} \mathrm{C}$, the volatile compositions after a further $24 \mathrm{~h}$ at $20^{\circ} \mathrm{C}$ were very close to those of the

272 tomatoes that had only been stored for $24 \mathrm{~h}$ at $20^{\circ} \mathrm{C}$. Impact of reconditioning was much

273 lower for long storage at $4{ }^{\circ} \mathrm{C}$.

274 The PCA map shows that the volatile compositions of the two lines were initially contrasted

275 and stayed clearly distinct during storage; however the evolution trends were affected

276 primarily by storage temperature.

277

278

\subsubsection{Evolution of LOX products}


279 The main group of volatiles consisted of the so-called LOX products (Table 5), most of which

280 correlated with and contributed strongly to axis 1 of the PCA (Fig. 3B), with the exception of

281 (E,E)-2,4-decadienal and 2-pentylfuran, close to axis 2, and (Z)-3-hexen-1-ol, which had an

282 intermediate behavior. LOX products are major determinants of the aroma of tomato

283 products. During storage at $20^{\circ} \mathrm{C}$ (Table 3), we noted little significant modification in the

284 LOX products, which mostly only tended to increase, nor in enzyme activities or substrate

285 concentrations (Table 6).

286 During storage at $4{ }^{\circ} \mathrm{C}$ (Table 3), the production of most LOX products decreased markedly;

287 after $24 \mathrm{~h}$ back at $20^{\circ} \mathrm{C}$, LOX products tended to recover in $\mathrm{LCx}$ but not in Levovil. For

288 volatile products from lipid degradation further downstream, such as (E,E)-2,4-decadienal, the

289 situation was much less clear-cut, and we found a trend towards increased concentrations for

290 prolonged storage at $4{ }^{\circ} \mathrm{C}$. In contrast, LOX activities remained fairly stable during storage

291 (Table 6), with values at $4{ }^{\circ} \mathrm{C}$ tending to decrease for LCx but increase for Levovil. HPL

292 activities initially decreased at $4{ }^{\circ} \mathrm{C}$ but stabilized after 1 (LCx) or 6 (Levovil) days. Linolenic

293 and linoleic acid concentrations actually increased during storage at $4{ }^{\circ} \mathrm{C}$ (Table 6).

\subsubsection{Time-course evolution of products from amino acid degradation}

296 Volatiles derived from amino acids (Table 5) were mostly strongly correlated with principal

297 component 1 (Fig. 3) but showed a diverse range of behaviours during storage. In particular,

298 2-isobutylthiazole was strongly correlated with and contributed to principal component 2.

299 Production of 2-isobutylthiazole increased markedly at $20^{\circ} \mathrm{C}$ in both lines (Table 5). The two

300 other products from leucine/isoleucine degradation, i.e. 3-methylbutanoic acid and 3-methyl-

301 1-butanol, were on the diagonal of principal components 1 and 2. 3-Methyl-1-butanol

302 concentration increased at $20^{\circ} \mathrm{C}$ in Levovil but not in $\mathrm{LCx}$, and reached similar levels in both

303 lines after 6 days of storage. Products from the phenylalanine pathway followed a similar 
304

305

306

307

pattern 3-methyl-1-butanol. Concentrations of leucine/isoleucine and phenylalanine degradation products were initially high in LCx and stayed high at $20^{\circ} \mathrm{C}$., whereas in Levovil they were initially low but increased markedly during storage at $20^{\circ} \mathrm{C}$. Volatiles originating from sulfur-containing amino acids, illustrated in Fig. 3 by 2-methylthioethanol, increased at $20{ }^{\circ} \mathrm{C}$ and for short storage at $4{ }^{\circ} \mathrm{C}$, but decreased upon prolonged storage at $4{ }^{\circ} \mathrm{C}$ in both lines. As a rule, volatiles originating from amino-acid degradation tended to increase during storage at $20{ }^{\circ} \mathrm{C}$ and decrease at $4{ }^{\circ} \mathrm{C}$, but the intensity of their variations were very different for $\mathrm{LCx}$ and Levovil.

\subsubsection{Time-course evolution of carotenoid derivatives}

Apocarotenoid volatiles are produced by oxidative cleavage of the various carotenoids present in tomato, of which the major compounds are lycopene and $\beta$-carotene. Apocarotenoids are generally described as having fruity or floral attributes, and have been shown (Vogel, Tieman, Sims, Odabasi, Clark, \& Klee, 2010) to contribute strongly to flavour acceptability. Most carotenoid-derived compounds were highly correlated with principal component 1 (Fig. 3), although specific groups emerged (Table 5). One of these groups, illustrated by 6-methyl-5hepten-2-one, a lycopene degradation product, was characterized by a marked increase during storage at $20^{\circ} \mathrm{C}$ but stable or slightly decreased concentrations at $4{ }^{\circ} \mathrm{C}$, with very little recovery during reconditioning. Another typical behaviour is that of dihydroactinidiolide, originating from $\beta$-carotene, which increased in all storage conditions. Carotenoid-derived volatiles thus showed different time-course evolution patterns during storage, with most increasing in storage at $20^{\circ} \mathrm{C}$ but some also increasing in storage at $4{ }^{\circ} \mathrm{C}$.

\subsubsection{Miscellaneous}


328

Phenylpropanoid derivatives eugenol, methylsalicylate and 2-methoxyphenol (Table 3), as noted above, were absent or present in only trace amounts in LCx. In Levovil, their concentrations did not vary significantly during storage at $20{ }^{\circ} \mathrm{C}$ but decreased markedly at 4 ${ }^{\circ} \mathrm{C}$. No particular trend could be noted for furaneol (Table 3) due to its low concentrations and high variability.

\section{Discussion}

4.1 Volatiles are lost during storage at $4{ }^{\circ} \mathrm{C}$

The observed time-course evolutions corroborated a loss of aroma for ripe tomatoes under cold storage. The consumer-perceived loss therefore has a biosynthetic origin and not only a physico-chemical origin due to eating a colder food. Reconditioning at room temperature as a strategy to mitigate this loss did not seem very efficient.

Storage at $20{ }^{\circ} \mathrm{C}$ increased the amounts of volatiles produced and changed their patterns. The LOX products stayed the most abundant class but their concentrations varied only moderately, with statistical significance depending on target compound. This is confirmed by the literature. Zhang, Zeng \& Li (2008) compared the volatile composition of mature red and "stale" tomatoes (storage at $25^{\circ} \mathrm{C}$, but no details of storage duration) by headspace solidphase microextraction. They found an increase in the relative area of hexanal and a decrease of (E)-2-hexenal. This is the pattern observed here for hexanal, while hexenal (sum of (E)-2and (Z)-3-hexenal) did not vary. Krumbein, Peters \& Brückner (2004) noted increases in hexanal, (E)-2-heptenal and (E,E)-2,4-decadienal in tomatoes stored at $20^{\circ} \mathrm{C}$ for up to 7 (cv Pronto), 10 (cv Mickey) and 21 days (cv Vanessa). Contrasted behaviours were observed for (E,E)-2,4-decadienal in LCx and Levovil. Ties \& Barringer (2012) also reported moderate increases in hexanal after 14-day storage of "Campari" tomatoes and an increase in (E)-2- 
352

353

hexenal production from the flesh only. There are also reports of very limited evolution in LOX pathway substrates and enzymes during storage at $20^{\circ} \mathrm{C}$, as observed by Ties \& Barringer (2012). Krumbein et al. (2004) and Maul et al. (2000) had already reported increased 6-methyl-5-hepten-2-one and geranylacetone during storage of tomatoes at $20{ }^{\circ} \mathrm{C}$. Few reports are available on the time-course evolution of volatiles originating from amino acids in ripe tomato. During storage at $20^{\circ} \mathrm{C}$, Krumbein et al. (2004) and Zhang et al. (2009) reported increased 2-isobutylthiazole and Maul et al. (2000) found increased 2+3methylbutanol. Concerning phenylpropanoid derivatives, Krumbein et al. (2004) observed an increase in methylsalicylate in three varieties of tomatoes stored at $20^{\circ} \mathrm{C}$. The main evolution in volatile production during storage at $20^{\circ} \mathrm{C}$ was a decrease of the relative proportion of LOX products, notably relative to the carotenoid degradation products. This can be linked to loss of the "green" or "grassy" notes as the tomatoes mature, whereas "fruity" aromas become more marked (Baldwin, Scott, Shewmaker, \& Schuch, 2000).

Tomato volatiles were strongly affected by storage at $4{ }^{\circ} \mathrm{C}$, though red-ripe fruits are less sensitive to cold than earlier maturation stages. The decrease in production of LOX compounds under cold conditions has been studied because they are major contributors to tomato aroma. Maul et al. (2000) had already noted a marked decrease in the production of LOX compounds (lipid-derived volatiles) during storage at low temperatures, but this loss cannot be explained in a straightforward manner, and in particular is not explained by a loss of substrate or global enzyme activity, as exemplified in Ties \& Barringer (2012) or Bai, Baldwin, Imahori, Kostenyuk, Burns, \& Brecht (2011). Bai et al. (2011) observed an increase in total LOX activity after 5-day storage at $5{ }^{\circ} \mathrm{C}$ and a decrease in HPL activity with some recovery after 4-day storage at $20^{\circ} \mathrm{C}$, while Ties \& Barringer (2012) found a slight increase in total LOX activity, confirming our results. Bai et al. (2011) also indicated that the 
377 divergence between enzyme activities (and transcript expression) and LOX product

378 production might be linked to substrate availability. However, as reported by Ties \&

379 Barringer (2012), the concentrations of the LOX substrates linoleic and linolenic acid actually

380 increased during storage (Table 2). This divergence is therefore most likely linked to the

381 existence of different isoforms of LOX expressed in ripening tomato. Griffiths, Prestage,

382 Linforth, Zhang, Taylor, \& Grierson (1999) reported no impact on generation of C6 aldehydes

383 and alcohols in antisense-transgenic tomatoes in which TomloxA and TomloxB were

384 inactivated, while the inactivation of TomloxC (Chen, Hackett, Walker, Taylor, Lin, \&

385 Grierson, 2004) led to a marked reduction in the production of hexanal, hexenal and hexanol.

386 Kovács, Fray, Tikunov, Graham, Bradley, Seymour et al. (2009), studying the effect of

387 ripening mutations on volatile synthesis, also showed that LOX compounds (fatty-acid

388 derived volatiles) appear intimately linked to TomloxC expression. Bai et al. (2011) studied

389 the expression of TomloxA, B, C and $D$ in chilled $\left(5\right.$ days at $\left.5{ }^{\circ} \mathrm{C}\right)$ tomatoes and found a

390 downregulation of all but TomloxD upon chilling, together with increased LOX activity. The

391 existence of a specific isoform downregulated during cold storage might explain the decrease

392 in LOX volatiles under cold storage without loss of substrates or global LOX activity.

393 The decrease in phenylpropanoid (eugenol and 2-methylphenol) concentrations in Levovil

394 during storage at $4{ }^{\circ} \mathrm{C}$ could actually be beneficial, leading to a loss (or at least a decrease)of

395 the "pharmaceutical" aftertaste.

396

4.2 Comparison of the two cultivars

398 The study was performed on two tomato lines known for their contrasted sensory attributes:

399 Levovil, characterized by its large fruits and "pharmaceutical" aftertaste, and LCx, an

400 introgressed line carrying five chromosome regions from the Cervil cherry tomato identified

401 as bearing the qtls for quality traits, notably for tomato aroma intensity in the Levovil 
402

403

404

405

406

407

408

409

410

411

412

413

414

415

416

417

418

419

420

421

422

background (Causse, Saliba-Colombani, Lecomte, Duffé, Rousselle, \& Buret, 2002; Chaib et al., 2006). The overall pattern of volatiles in the freshly-harvested red fruits (Tables 3 to 5) confirms previous research (Birtic et al., 2009; Zanor, Eambla, Chaib, Steppa, Medina, Granell, et al., 2009). The difference in total volatiles production could be partially explained by the smaller size and therefore higher peel-to-flesh ratio of LCx, as higher concentrations of volatiles and their precursors are found in tomato peel (Ties \& Barringer, 2012). Eugenol and 2-methoxyphenol are responsible for the presence of "pharmaceutical" aftertaste in Levovil (Causse et al., 2002; Chaib et al., 2006; Zanor al., 2009) and were absent in LCx, as in its Cervil introgression parent (Birtic et al., 2009). The difference between the cultivars could be due to different glycosidation patterns (Tikunov, de Vos, Paramas, Hall, \& Bovy, 2010), although Birtic et al. (2009) did not find high accumulation of the corresponding glycosides in Cervil. The two lines also differed in terms of volatiles derived from phenylalanine and sulphur-containing amino acids, though again this was less marked than in the Cervil/Levovil comparison (Zanor et al., 2009). Smaller differences could be noted for volatiles derived from the LOX pathway; concentrations of fatty acid precursors and enzyme activities (LOX and HPL) were also quite similar. The fatty acid contents were in agreement with the levels reported by Gray, Prestage, Linforth, \& Taylor (1999). Linoleic acid was by far the predominant fatty acid, with linoleic/linolenic ratio of 7.7 for Levovil and 6.1 for LCx, which are high values in comparison to those reported by Gray et al. (1999) and Ties \& Barringer (2012). Hexanal originates from linoleic acid while hexenal originates from linolenic acid. The hexanal/hexenal ratios ( 0.4 in Levovil, 0.5 in LCx) were about 10 -fold lower than the linoleic/linolenic acid ratio, but still much higher than those found by Gray et al. (1999). This indicates preferential conversion of linolenic acid, as was also found by Ties \& Barringer (2012). The two lines exhibited the expected characteristics and contrasts, both in terms of physical characteristics and volatiles production, though the differential was less visible than 
427

428

430

431

432

433

434

435

436

437

438

440

441

442

443

444

445

446

447

with Cervil, the origin of the five introgressed chromosome region (Birtic et al., 2009; Chaib

et al., 2006). The main differences concern volatile production, which was much higher in

LCx, and the phenylpropanoid pathway, with only Levovil producing phenylpropanoid volatiles.

\section{Conclusion}

The storage conditions of red-ripe tomatoes modified both global volatiles production and volatiles profile. Cold storage was detrimental for tomato aroma even when starting from redripe fruits. Conservation at $4{ }^{\circ} \mathrm{C}$ led to a drop in volatile production and loss of aroma compounds. Storing tomatoes in a refrigerator thus jeopardizes all the efforts carried out throughout the supply chain to deliver a high-quality produce. Only in the earliest stages of fridge storage ( $<1$ week) could the aroma be restored by reconditioning the tomatoes at room temperature for $24 \mathrm{~h}$. This conditioning can still have some positive effects after long ( $>2$ weeks) fridge storage, though with a marked imbalance compared to the fresh tomato. In particular, there was an increase of the relative importance of carotenoid degradation products and even some of the down-chain LOX products such as (EE)-2,4-decadienal. Aroma profiles of red-ripe tomatoes were positively impacted by storage at $20^{\circ} \mathrm{C}$, with an overall increase in volatile production. This was accompanied by a possible decrease of the "pharmaceutical" aftertaste in Levovil and an increase in the fruity notes brought by carotenoid degradation products in both Levovil and LCx. Clearly, conservation at room temperature should be advocated for consumers. Therefore, further consumer information efforts as well as specific storage guidelines could be highly beneficial for consumer perceptions of tomato quality. 


\section{Acknowledgements}

453 This work was funded by project ANR-06-PNRA-009 QualitomFil "Elaboration et

454 valorisation de la qualité organoleptique et nutritionnelle de la tomate tout au long de la

455 filière" program. The authors thank Antony Rech, Patrice Reling, and Marielle Bogé for their 456 excellent technical help.

457

458 References

459 Auerswald, H., Peters, P., Brückner, B., Krumbein, A., \& Kuchenbuch, R. (1999). Sensory

460 analysis and instrumental measurements of short-term stored tomatoes (Lycopersicon

461 esculentum Mill.). Postharvest Biology and Technology, 15(3), 323-334.

462 Bai, J.H., Baldwin, E.A., Imahori, Y., Kostenyuk, I., Burns, J., \& Brecht, J.K. (2011).

463 Chilling and heating may regulate C6 volatile aroma production by different mechanisms in

464 tomato (Solanum lycopersicum) fruit. Postharvest Biology and Technology, 60(2), 111-120.

465 Baldwin, E.A., Scott, J.W., Shewmaker, C.K., \& Schuch, W. (2000). Flavour trivia and

466 tomato aroma: Biochemistry and possible mechanisms for control of important aroma

467 components. HortScience, 35(6), 1013-1022.

468 Baysal, T., \& Demirdoven, A. (2007). Lipoxygenase in fruits and vegetables: A review.

469 Enzyme and Microbial Technology, 40(4), 491-496. 
470 Birtic, S., Ginies, C., Causse, M., Renard, C. M. G. C., \& Page, D. (2009). Changes in

471 volatiles and glycosides during fruit maturation of two contrasted tomato (Solanum

472 lycopersicum) lines. Journal of Agricultural and Food Chemistry, 57(2), 591-598.

Box, G.E.P., Hunter, W.G., \& Hunter, J. S. (1978). Statistics for Experimenters: John Wiley and Sons, New York.

Bradford, M. M. (1976). Rapid and sensitive method for quantitation of microgram quantities of protein utilizing principle of protein-dye binding. Analytical Biochemistry, 72(1-2), 248254.

Causse, M., Saliba-Colombani, V., Lecomte, L., Duffé, P., Rousselle, P., \& Buret, M. (2002). QTL analysis of fruit quality in fresh market tomato: a few chromosome regions control the variation of sensory and instrumental traits. Journal of Experimental Botany, 53(377), 20892098.

Chaib, J., Lecomte, L., Buret, M., \& Causse, M. (2006). Stability over genetic backgrounds, generations and years of quantitative trait locus (QTLs) for organoleptic quality in tomato. Theoretical and Applied Genetics, 112(5), 934-944.

Chen, G.P., Hackett, R., Walker, D., Taylor, A., Lin, Z.F., \& Grierson, D. (2004). Identification of a specific isoform of tomato lipoxygenase (TomloxC) involved in the generation of fatty acid-derived flavour compounds. Plant Physiology, 136(1), 2641-2651.

de Leon-Sanchez, F.D., Pelayo-Zaldivar, C., Rivera-Cabrera, F., Ponce-Valadez, M., AvilaAlejandre, X., Fernandez, F.J., Escalona-Buendia, H.B., \& Perez-Flores, L.J. (2009). Effect of refrigerated storage on aroma and alcohol dehydrogenase activity in tomato fruit. Postharvest Biology and Technology, 54(2), 93-100. 
492 Gray, D.A., Prestage, S., Linforth, R.S.T., \& Taylor, A.J. (1999). Fresh tomato specific

493 fluctuations in the composition of lipoxygenase-generated C6 aldehydes. Food Chemistry, 494 64(2), 149-155

495 Griffiths, A., Prestage, S., Linforth, R., Zhang, J., Taylor, A., \& Grierson, D. (1999). Fruit496 specific lipoxygenase suppression in antisense-transgenic tomatoes. Postharvest Biology and 497 Technology, 17(3), 163-173.

498 Hauck, T., Hübner, Y., Brühlmann, F., \& Schwab, W. (2003). Alternative pathway for the 499 formation of 4,5-dihydroxy-2,3-pentanedione, the proposed precursor of 4-hydroxy-5-methyl$5003(2 \mathrm{H})$-furanone as well as autoinducer-2, and its detection as natural constituent of tomato 501 fruit. Biochimica et Biophysica Acta (BBA) - General Subjects, 1623(2-3), 109-119.

502 Kovács, K., Fray, R.G., Tikunov, Y., Graham, N., Bradley, G., Seymour, G.B., Bovy, A.G., \& 503 Grierson, D. (2009). Effect of tomato pleiotropic ripening mutations on flavour volatile 504 biosynthesis. Phytochemistry, 70(8), 1003-1008.

505 Krumbein, A., Peters, P., \& Brückner, B. (2004). Flavour compounds and a quantitative 506 descriptive analysis of tomatoes (Lycopersicon esculentum Mill.) of different cultivars in 507 short-term storage. Postharvest Biology and Technology, 32(1), 15-28.

508 Lewinsohn, E., Sitrit, Y., Bar, E., Azulay, Y., Ibdah, M., Meir, A., Yosef, E., Zamir, D., \& 509 Tadmor, Y. (2005). Not just colours-carotenoid degradation as a link between pigmentation 510 and aroma in tomato and watermelon fruit. Trends in Food Science \& Technology, 16(9), 407511415. 
512 Linforth, R.S.T., Savary, I., Pattenden, B., \& Taylor, A.J. (1994). Volatile compounds found

513 in expired air during eating of fresh tomatoes and in the headspace above tomatoes. Journal of

514 the Science of Food and Agriculture, 65(2) 241-247.

515 Mathieu, S., Cin, V.D., Fei, Z.J., Li, H., Bliss, P., Taylor, M.G., Klee, H.J., \& Tieman, D.M.

516 (2009). Flavour compounds in tomato fruits: identification of loci and potential pathways

517 affecting volatile composition. Journal of Experimental Botany, 60(1), 325-337.

518 Maul, F., Sargent, S. A., Sims, C.A., Baldwin, E.A., Balaban, M.O., \& Huber, D.J. (2000).

519 Tomato flavour and aroma quality as affected by storage temperature. Journal of Food

$520 \quad$ Science, 65(7), 1228-1237.

521 Mayer, F., Takeoka, G.K., Buttery, R.G., Whitehand, L.C., Naim, M.N., \& Rabinowitch, H.D.

522 (2008). Studies on the aroma of five fresh tomato cultivars and the precursors of cis- and

523 trans-4,5-epoxy-(E)-2-decenals and methional. Journal of Agricultural and Food Chemistry,

$52456(10), 3749-3757$.

525 Riley, J.C.M., \& Thompson, J.E. (1998). Ripening-induced acceleration of volatile aldehyde

526 generation following tissue disruption in tomato fruit. Physiologia Plantarum, 104, 571-576.

527 Riley, J.C.M., Willemot, C., \& Thompson, J.E. (1996). Lipoxygenase and hydroperoxide

528 lyase activities in ripening tomato fruit. Postharvest Biology and Technology, 7(1/2), 97-107.

529 Robinson, D.S., Wu, Z.C., Domoney, C., \& Casey, R. (1995). Lipoxygenases and the quality 530 of foods. Food Chemistry, 54(1), 33-43.

531 Rodrigo, D., Jolie, R., Van Loey, A., \& Hendrickx, M. (2007). Thermal and high pressure

532 stability of tomato lipoxygenase and hydroperoxide lyase. Journal of Food Engineering, $53379(2), 423-429$ 
534 Schäfer, K. (1998). Accelerated solvent extraction of lipids for determining the fatty acid

535 composition of biological material. Analytica Chimica Acta, 358(1), 69-77.

536 Schwab, W., Davidovich-Rikatani, R., \& Lewinsohn, E. (2008). Biosynthesis of plant-derived

537 flavour compounds. The Plant Journal, 54(4), 712-732.

538 Stern, D.J., Buttery, R.G., Teranishi, R., Ling, L., Scott, K., \& Cantwell, M. (1994). Effect of

539 storage and ripening on fresh tomato quality, Part 1. Food Chemistry, 49(3), 225-231.

540 Surrey, K. (1964). Spectrophotometric method for determination of lipoxidase activity. Plant

541 Physiology, 39(1), 65-70.

542 Ties, P., \& Barringer, S. (2012). Influence of lipid content and lipoxygenase on flavour

543 volatiles in the tomato peel and flesh. Journal of Food Science, 77(7), C830-C837.

544 Tikunov, Y., Lommen, A., de Vos, C.H.R., Verhoeven, H.A., Bino, R.J., Hall, R.D., \& Bovy,

545 A.G. (2005). A novel approach for nontargeted data analysis for metabolomics. Large-scale

546 profiling of tomato fruit volatiles. Plant Physiology, 139(3), 1125-1137.

547 Tikunov, Y.M., de Vos, R.C.H., Paramas, A.M.G., Hall, R.D., \& Bovy, A.G. (2010). A role

548 for differential glycoconjugation in the emission of phenylpropanoid volatiles from tomato

549 fruit discovered using a metabolic data fusion approach. Plant Physiology, 152(1), 55-70.

550 Trad, M., Ginies, C., Gaaliche, B., Renard, C.M.G.C., \& Mars, M. (2012). Does pollination

551 affect aroma development in ripened fig [Ficus carica L.] fruit? Scientia Horticulturae, 134, $552 \quad 93-99$. 
553

554

555

556

557

558

559

560

561

562

563

564

565

566

567

568

569

Ullrich, F., \& Grosch, W. (1987). Identification of the most intense volatile flavour

compounds formed during autoxidation of linoleic acid. Zeitschrift für

Lebensmitteluntersuchung und -forschung A, 184(4), 277-282.

Vick, B.A. (1991). A spectrophotometric assay for hydroperoxide lyase. Lipids, 26(4), 315320.

Vogel, J.T., Tieman, D.M., Sims, C.A., Odabasi, A.Z., Clark, D.G., \& Klee, H.J. (2010).

Carotenoid content impacts flavour acceptability in tomato (Solanum lycopersicum). Journal of the Science of Food and Agriculture, 90(13), 2233-2240.

Xu, Y.C., \& Barringer, S. (2010). Comparison of volatile release in tomatillo and different varieties of tomato during chewing. Journal of Food Science, 75(4), C352-C358.

Zanor, M.I., Rambla, J.L., Chaib, J., Steppa, A., Medina, A., Granell, A., Fernie, A.R., \& Causse, M. (2009). Metabolic characterization of loci affecting sensory attributes in tomato allows an assessment of the influence of the levels of primary metabolites and volatile organic contents. Journal of Experimental Botany, 60(7), 2139-2154.

Zhang, Z.M., Zeng, D.D., \& Li, G.K. (2008). Study of the volatile composition of tomato during storage by a combination sampling method coupled with gas chromatography/mass spectrometry. Journal of the Science of Food and Agriculture, 88(1), 116-124. 
570

571

572

573

574

575

576

577

578

579

580

581

582

583

584

585

586

587

588

589

590

591

592

593

\section{Caption to figures}

Figure 1: Time-course evolution of firmness and hue angle for LCx and Levovil tomatoes stored at $20{ }^{\circ} \mathrm{C}$ and $4{ }^{\circ} \mathrm{C}$. Each point is the average (and standard deviation) of three replicates of 5 tomatoes each.

○: $\mathrm{LCx}$, stored at $20{ }^{\circ} \mathrm{C} ; \triangle: \mathrm{LCx}$, stored at $4{ }^{\circ} \mathrm{C} ; \boldsymbol{\Delta}: \mathrm{LCx}$; stored at $4{ }^{\circ} \mathrm{C}$ then reconditioned for $24 \mathrm{~h}$ at $20^{\circ} \mathrm{C}$.

$\square:$ Levovil, stored at $20^{\circ} \mathrm{C} ; \diamond:$ Levovil, stored at $4{ }^{\circ} \mathrm{C} ;:$ Levovil, stored at $4{ }^{\circ} \mathrm{C}$ then reconditioned for $24 \mathrm{~h}$ at $20^{\circ} \mathrm{C}$.

Figure 2: Time-course evolution of the sum of volatiles of LCx and Levovil tomatoes stored at $20^{\circ} \mathrm{C}$ and $4{ }^{\circ} \mathrm{C}$. Each point is the average (and standard deviation) of three replicates of 5 tomatoes each.

○: $\mathrm{LCx}$, stored at $20{ }^{\circ} \mathrm{C} ; \triangle$ : $\mathrm{LCx}$, stored at $4{ }^{\circ} \mathrm{C} ; \mathbf{\Lambda}: \mathrm{LCx}$, stored at $4{ }^{\circ} \mathrm{C}$ then reconditioned for $24 \mathrm{~h}$ at $20^{\circ} \mathrm{C}$.

$\square$ : Levovil, stored at $20{ }^{\circ} \mathrm{C} ; \diamond$ : Levovil, stored at $4{ }^{\circ} \mathrm{C}$; $:$ Levovil, stored at $4{ }^{\circ} \mathrm{C}$ then reconditioned for $24 \mathrm{~h}$ at $20^{\circ} \mathrm{C}$.

Figure 3: Principal component analysis of the volatiles composition of tomatoes as a function of their storage conditions.

Variables were selected based on a PCA carried out with all variables and all samples,

followed by eliminating all but one of each highly correlated variables group. Each point is the average of three replicates of 5 tomatoes each.

Panel A: map of samples (tomatoes) projected onto the principal components 1 x 2 plane. 
594 Coding of the sample points: L, levovil; X, LCx; the first number gives storage temperature,

595 followed by duration of storage. The " +1 " indicates that the sample was left for 1 day at $20{ }^{\circ} \mathrm{C}$

596 after storage at $4{ }^{\circ} \mathrm{C}$. Thus L_4_15+1 designated tomatoes of the Levovil variety, stored at 4

$597{ }^{\circ} \mathrm{C}$ for 15 days then left for 1 day at $20{ }^{\circ} \mathrm{C}$ to recover volatile production. Blue denotes storage

598 at $4{ }^{\circ} \mathrm{C}$, and red denotes storage at $20^{\circ} \mathrm{C}$.

599 Panel B: variables (volatile compounds) projected on the correlation circle defined by

600 principal components $1 \times 2$. Each arrow corresponds to one of the variables. The colours

601 denote biochemical origins: blue for volatiles derived from fatty acid degradation by LOX,

602 purple from carotenoids, green for amino acids, orange for phenylpropanoids, and red from

603 carbohydrates.

604 
606 Table 1: Volatile compounds quantified: retention index, odourant potential and biosynthetic origin

\begin{tabular}{|c|c|c|c|}
\hline Volatile compound & RI & $\begin{array}{l}\text { Contribution to } \\
\text { tomato aroma }\end{array}$ & Biosynthetic origin \\
\hline Hexanal & a & ++ & Lipid $^{\mathrm{c}, \mathrm{e}}$ \\
\hline (E)-2-hexenal & a & + & Lipid $^{\mathrm{c}, \mathrm{e}}$ \\
\hline (Z)-3-hexenal & a & +++ & Lipid $^{\mathrm{c}, \mathrm{e}}$ \\
\hline 1-penten-3-one & a & + & Lipid $^{\mathrm{c}, \mathrm{e}}$ \\
\hline (E)-2-pentenal & 1115 & & Lipid $^{\mathrm{c}, \mathrm{e}}$ \\
\hline 1-penten-3-ol & 1168 & & Lipid $^{\mathrm{c}, \mathrm{e}}$ \\
\hline 3-methyl-1-butanol & 1219 & + & Leucine/isoleucine $^{c, e}$ \\
\hline 2-pentylfuran & 1245 & & Lipid $^{c}$ \\
\hline 1-pentanol & 1262 & & Lipid $^{c, e}$ \\
\hline 2-methylthioacetaldehyde & 1282 & & Sulfur-containing amino acid ${ }^{\mathrm{b}, \mathrm{f}}$ \\
\hline 1-octen-3-one & 1313 & + & Lipid $^{\text {b, h }}$ \\
\hline 2-hexanol & 1326 & & Lipid $^{\mathrm{c}}$ \\
\hline (Z)-2-heptenal & 1341 & & Lipid $^{c}$ \\
\hline 6-methyl-5-hepten-2-one & 1354 & & Open chain carotenoid ${ }^{\mathrm{c}}$, lycopene $\mathrm{e}^{\mathrm{e}}$ \\
\hline 1-hexanol & 1366 & & Lipid $^{\mathrm{e}}$ \\
\hline (Z)-3-hexen-1-ol & 1399 & & Lipid $^{\mathrm{e}}$ \\
\hline 2-isobutylthiazole & 1422 & + & Leucine/isoleucine $^{\mathrm{c}, \mathrm{e}}$ \\
\hline (E)-2-octenal & 1449 & + & \\
\hline Methional & 1470 & + & Sulfur-containing amino acid ${ }^{\mathrm{b}, \mathrm{f}}$ \\
\hline Benzaldehyde & 1550 & & Phenylalanine $^{\mathrm{e}}$ \\
\hline 2-methylthioethanol & 1554 & & Sulfur-containing amino acid $^{f}$ \\
\hline$\beta$-cyclocitral & 1642 & & Cyclic carotenoid $^{\mathrm{c}}, \beta$-carotene ${ }^{\mathrm{d}}$ \\
\hline Phenylacetaldehyde & 1671 & ++ & Phenylalanine $^{e}$ \\
\hline 3-methylbutanoic acid & 1701 & + & Leucine/isoleucine $^{\mathrm{c}, \mathrm{e}}$ \\
\hline (E,E)-2,4-nonadienal & 1723 & & Lipid $^{\text {b }}$ \\
\hline 3-methylthiopropanol & 1741 & & Sulfur-containing amino acid $^{\mathrm{f}}$ \\
\hline Geranial & 1754 & & Open chain carotenoid ${ }^{\mathrm{c}}$, lycopene \\
\hline (E,Z)-2,4-decadienal & 1786 & +++ & Lipid $^{c}$ \\
\hline Methyl salicylate & 1804 & & Phenylpropanoid $^{c}$ \\
\hline (E,E)-2,4-decadienal & 1820 & +++ & Lipid $^{\mathrm{c}}$ \\
\hline Geranylacetone & 1874 & & $\begin{array}{l}\text { Open chain carotenoid }{ }^{\mathrm{c}}, \text { phytoene }^{\text {chen }} \\
\text { phytofluene }^{\mathrm{d}}\end{array}$ \\
\hline 2-methoxyphenol & 1889 & & Phenylpropanoid ${ }^{\mathrm{c}}$ \\
\hline Benzyl alcohol & 1905 & & Phenylalanine $^{\mathrm{e}}$ \\
\hline 2-phenylethanol & 1939 & & Phenylalanine $^{\mathrm{e}}$ \\
\hline$\beta$-ionone & 1962 & + & Cyclic carotenoid $^{c}, \beta$-carotene ${ }^{\mathrm{d}}$ \\
\hline Cis-4,5-epoxy-(E)--2-decenal & 2005 & & Lipid $^{\text {b }}$ \\
\hline 5,6-Epoxy $\beta$-ionone & 2016 & & Cyclic carotenoid $^{\mathrm{c}}, \beta$-carotene ${ }^{\mathrm{d}}$ \\
\hline Trans-4,5-epoxy-(E)--2-decenal & 2025 & ++ & Lipid $^{\text {b }}$ \\
\hline Furaneol & 2057 & +++ & Carbohydrates $^{\mathrm{f}, \mathrm{g}}$ \\
\hline $\begin{array}{l}\text { Pseudo-ionone (unknown } \\
\text { configuration) }\end{array}$ & 2154 & & Cyclic carotenoid ${ }^{\mathrm{c}}, \beta$-carotene $\mathrm{d}^{\mathrm{d}, \mathrm{f}}$ \\
\hline
\end{tabular}




\begin{tabular}{|c|c|c|c|}
\hline Eugenol & 2197 & + & Phenylpropanoid $^{\mathrm{c}}$ \\
\hline 4-vinyl-2-methoxyphenol & 2225 & & Phenylpropanoid ${ }^{\mathrm{c}}$ \\
\hline Dihydroactiniodiolide & 2387 & & $\beta$-carotene ${ }^{\mathrm{d}}$ \\
\hline Farnesylacetone (unknown & 2389 & & Phytoene, phytofluene ${ }^{\mathrm{d}}$ \\
\hline
\end{tabular}
configuration)

608 c: from Tikunov, Lommen, de Vos, Verhoeven, Bino, Hall et al. (2005); d: from Lewinsohn, Sitrit, Bar, Azulay,

609 Ibdah, Meir et al. (2005); e: from Mathieu, Cin, Fei, Li, Bliss, Taylor, et al. (2009); f: from Schwab,

610 Davidovitch-Rikatani, \& Lewinsohn (2008); g: from Hauck, Hübner, Brühlmann \& Schwab (2003); h: from

611 Ullrich \& Grosch (1987). 
Table 2: Time-course evolution of the physical characteristics of tomatoes during storage at different temperatures. For all data, $\mathrm{n}=3$ repetitions of 5 tomatoes each.

\begin{tabular}{|c|c|c|c|c|c|c|c|}
\hline \multicolumn{3}{|c|}{ Storage } & \multirow[b]{2}{*}{$\begin{array}{l}\text { Weight } \\
(\mathrm{g})\end{array}$} & \multirow[b]{2}{*}{$\begin{array}{c}\text { Firmness } \\
(\mathrm{N})\end{array}$} & \multicolumn{3}{|c|}{ Colour } \\
\hline & Temp & $\begin{array}{l}\text { Duration } \\
\text { (days) }\end{array}$ & & & $\mathrm{L}^{*}$ & $\mathrm{C}^{*}$ & $\begin{array}{c}\mathrm{h}^{*} \\
\text { (degrees) }\end{array}$ \\
\hline \multirow[t]{8}{*}{ Levovil } & & 0 & 128 & 24.5 & 37.9 & 31.9 & 43.2 \\
\hline & $20^{\circ} \mathrm{C}$ & 1 & 129 & 23.6 & 37.4 & 30.4 & 44.9 \\
\hline & & 3 & 123 & 21.4 & 37.2 & 30.2 & 43.5 \\
\hline & & 6 & 129 & 17.1 & 37.3 & 31.9 & 41.9 \\
\hline & $4{ }^{\circ} \mathrm{C}$ & 1 & 125 & 26.2 & 37.4 & 32.8 & 43.5 \\
\hline & & 6 & 129 & 18.3 & 38.4 & 32.1 & 46.5 \\
\hline & & 15 & 127 & 14.0 & 38.3 & 31.9 & 49.7 \\
\hline & & 30 & 125 & 15.5 & 37.0 & 28.3 & 49.6 \\
\hline \multicolumn{8}{|c|}{$4^{\circ} \mathrm{C}+1$ day 20} \\
\hline \multirow{4}{*}{\multicolumn{2}{|c|}{${ }^{\circ} \mathrm{C}$}} & 1 & 119 & 26.7 & 37.6 & 32.2 & 42.2 \\
\hline & & 6 & 130 & 16.9 & 37.2 & 31.8 & 44.1 \\
\hline & & 15 & 127 & 17.6 & 37.6 & 29.4 & 47.9 \\
\hline & & 30 & 125 & 15.8 & 37.0 & 27.5 & 48.8 \\
\hline \multirow[t]{8}{*}{$\mathrm{LCx}$} & & 0 & 31 & 40.3 & 37.8 & 30.6 & 42.7 \\
\hline & $20^{\circ} \mathrm{C}$ & 1 & 27 & 40.0 & 37.9 & 30.7 & 39.5 \\
\hline & & 3 & 27 & 36.0 & 36.3 & 30.2 & 37.9 \\
\hline & & 6 & 29 & 26.1 & 36.8 & 30.1 & 38.4 \\
\hline & $4{ }^{\circ} \mathrm{C}$ & 1 & 29 & 37.6 & 38.1 & 30.0 & 41.0 \\
\hline & & 6 & 31 & 37.7 & 36.7 & 29.6 & 39.7 \\
\hline & & 15 & 31 & 20.6 & 35.4 & 28.9 & 40.0 \\
\hline & & 30 & 33 & 31.6 & 35.3 & 30.5 & 41.1 \\
\hline \multicolumn{8}{|c|}{$4^{\circ} \mathrm{C}+1$ day 20} \\
\hline \multirow[t]{4}{*}{${ }^{\circ} \mathrm{C}$} & & 1 & 31 & 41.1 & 36.4 & 30.0 & 39.3 \\
\hline & & 6 & 30 & 30.8 & 36.1 & 28.8 & 39.6 \\
\hline & & 15 & 32 & 22.3 & 36.0 & 28.4 & 40.0 \\
\hline & & 30 & 30 & 16.6 & 37.1 & 28.6 & 42.8 \\
\hline Pooled. & tandard & viation & $42 / 6$ & 5.4 & 1.4 & 2.9 & 2.5 \\
\hline
\end{tabular}




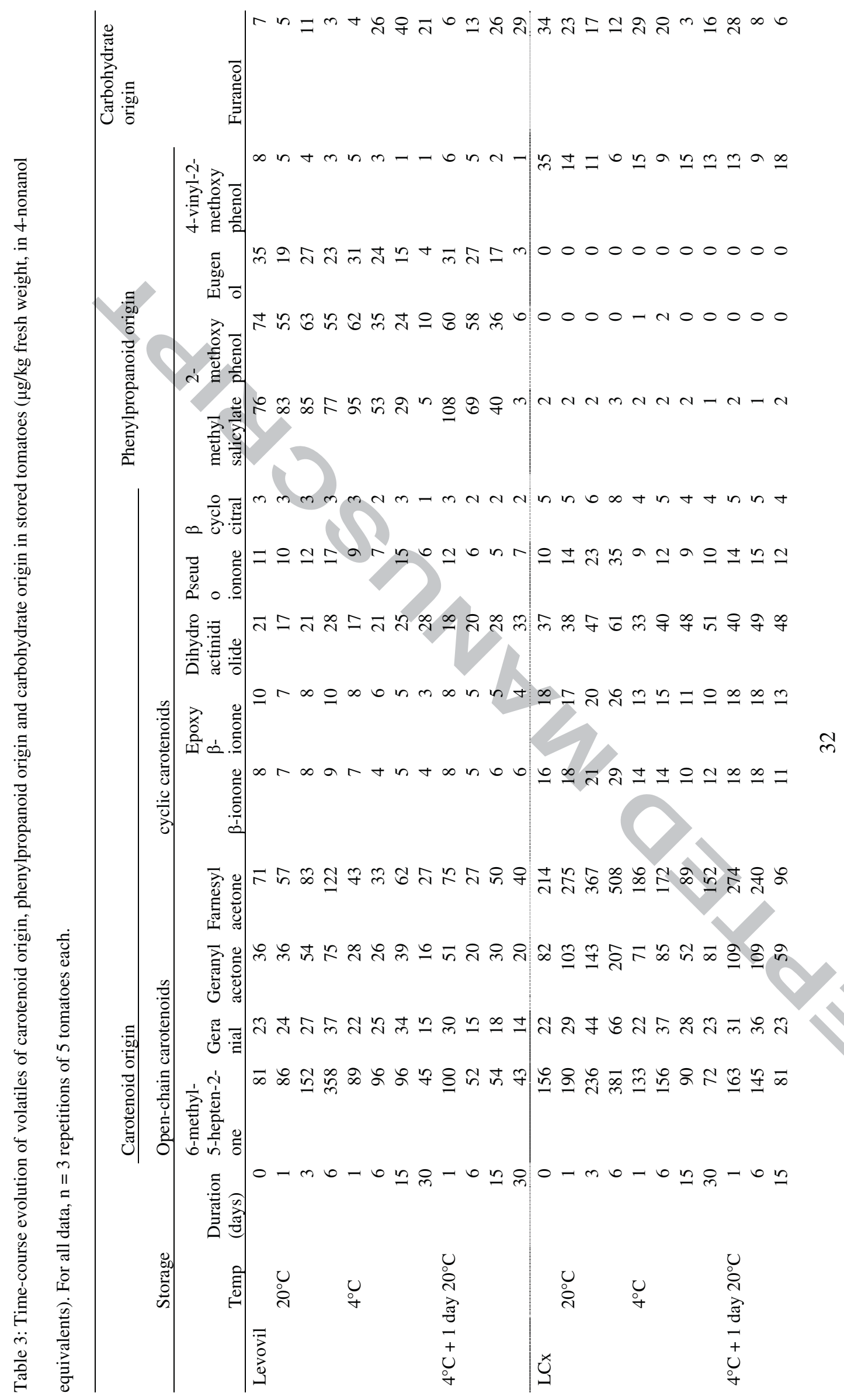




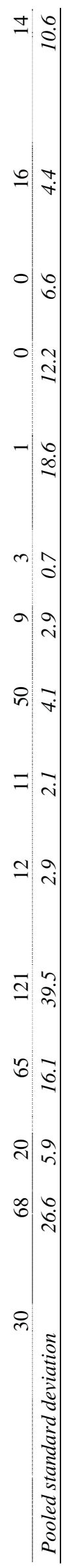




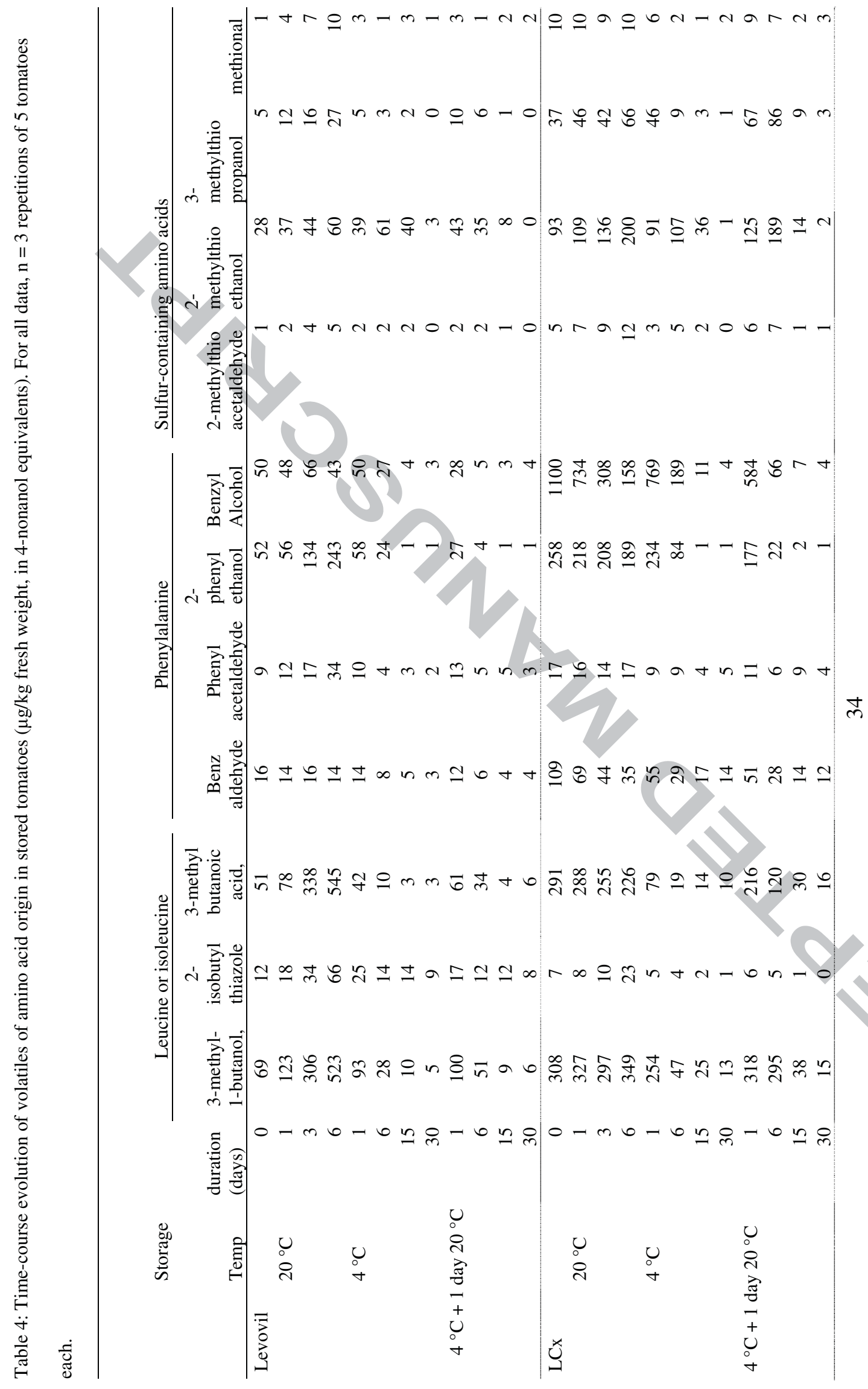




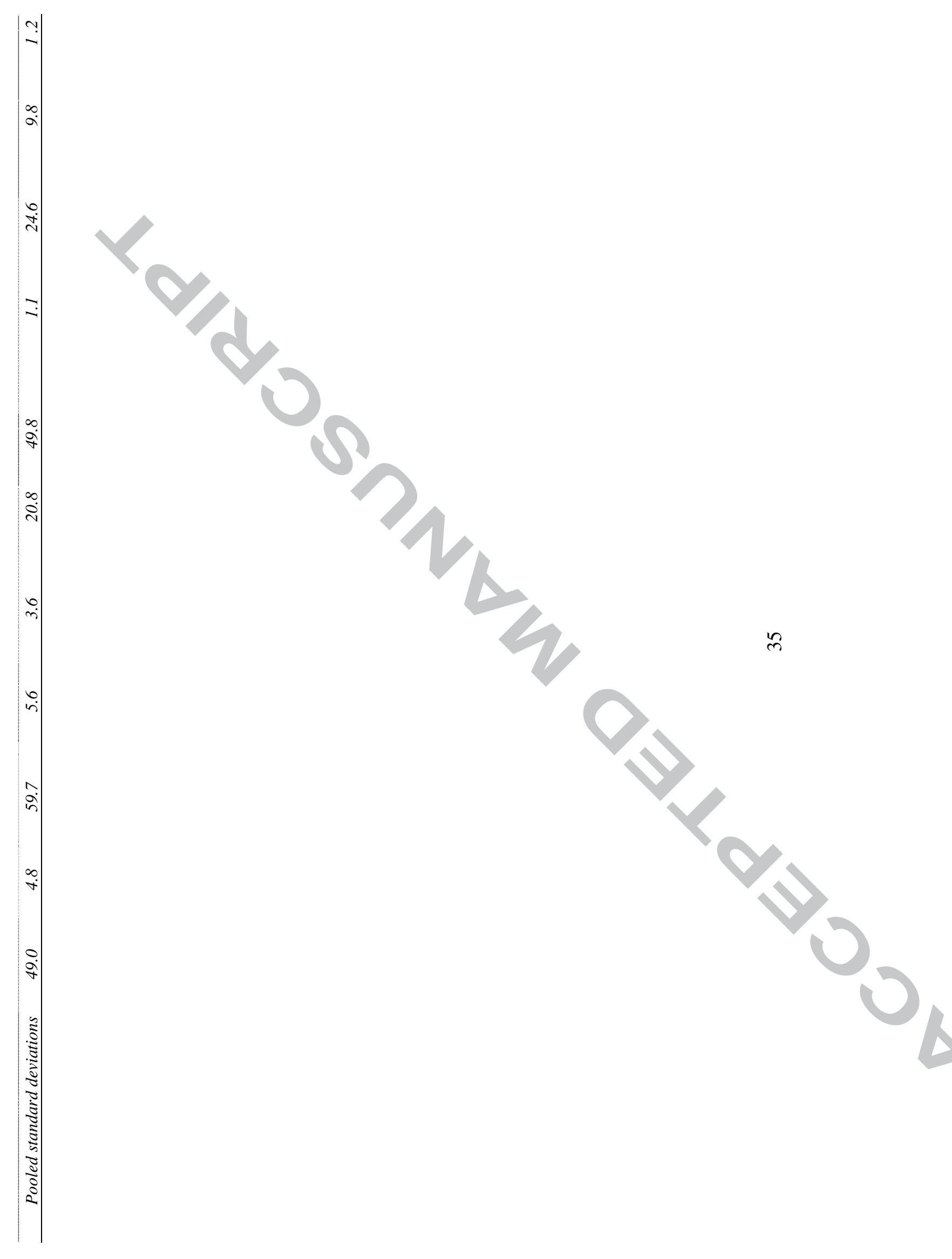




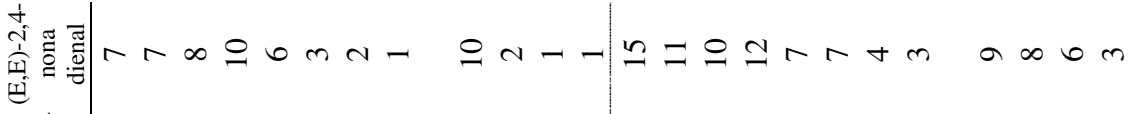

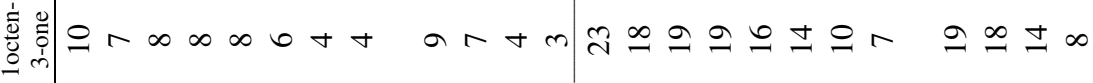

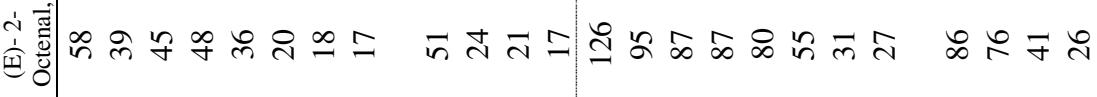

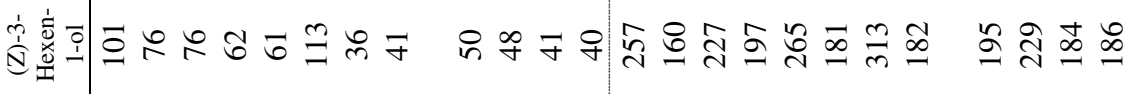

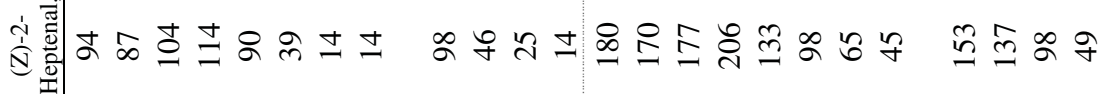

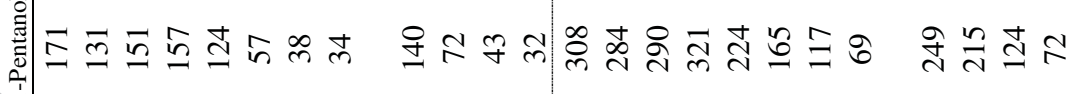

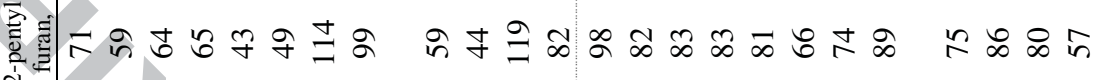

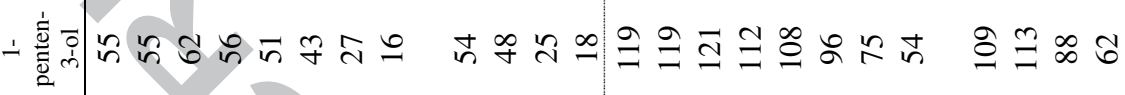

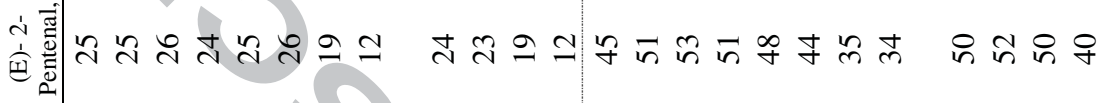

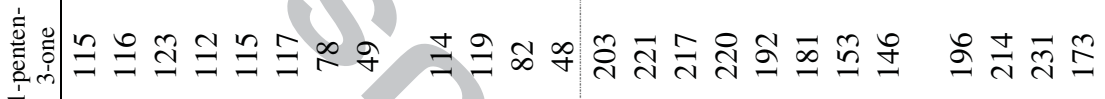

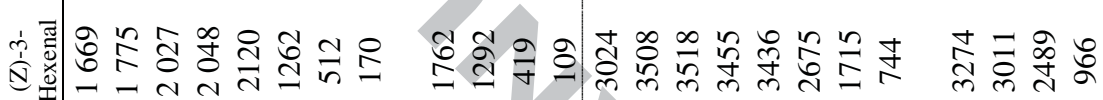

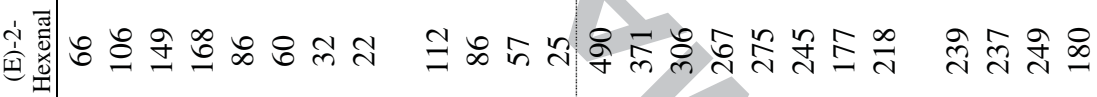

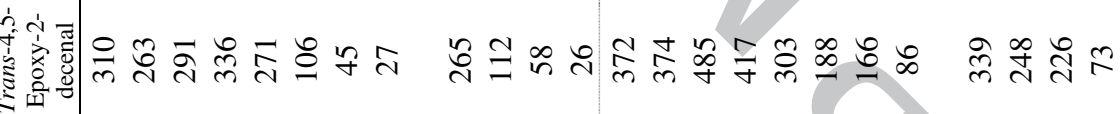

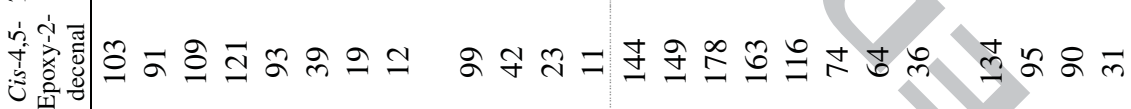
苞 造

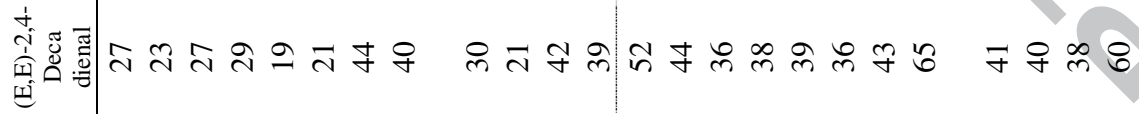

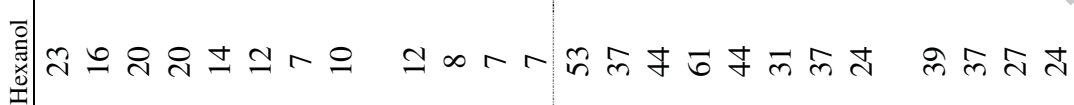

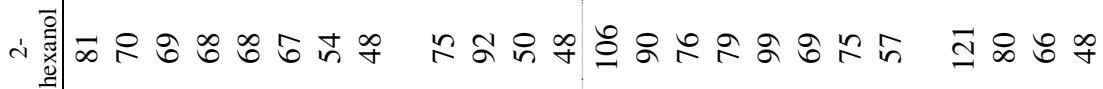

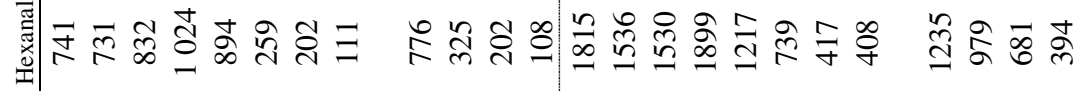

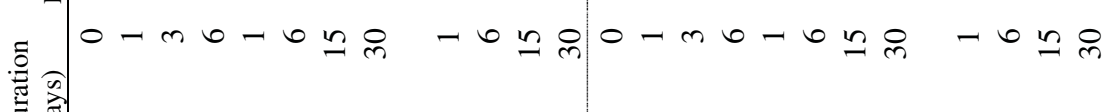
产 용 :

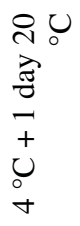

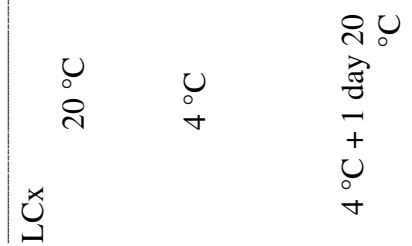




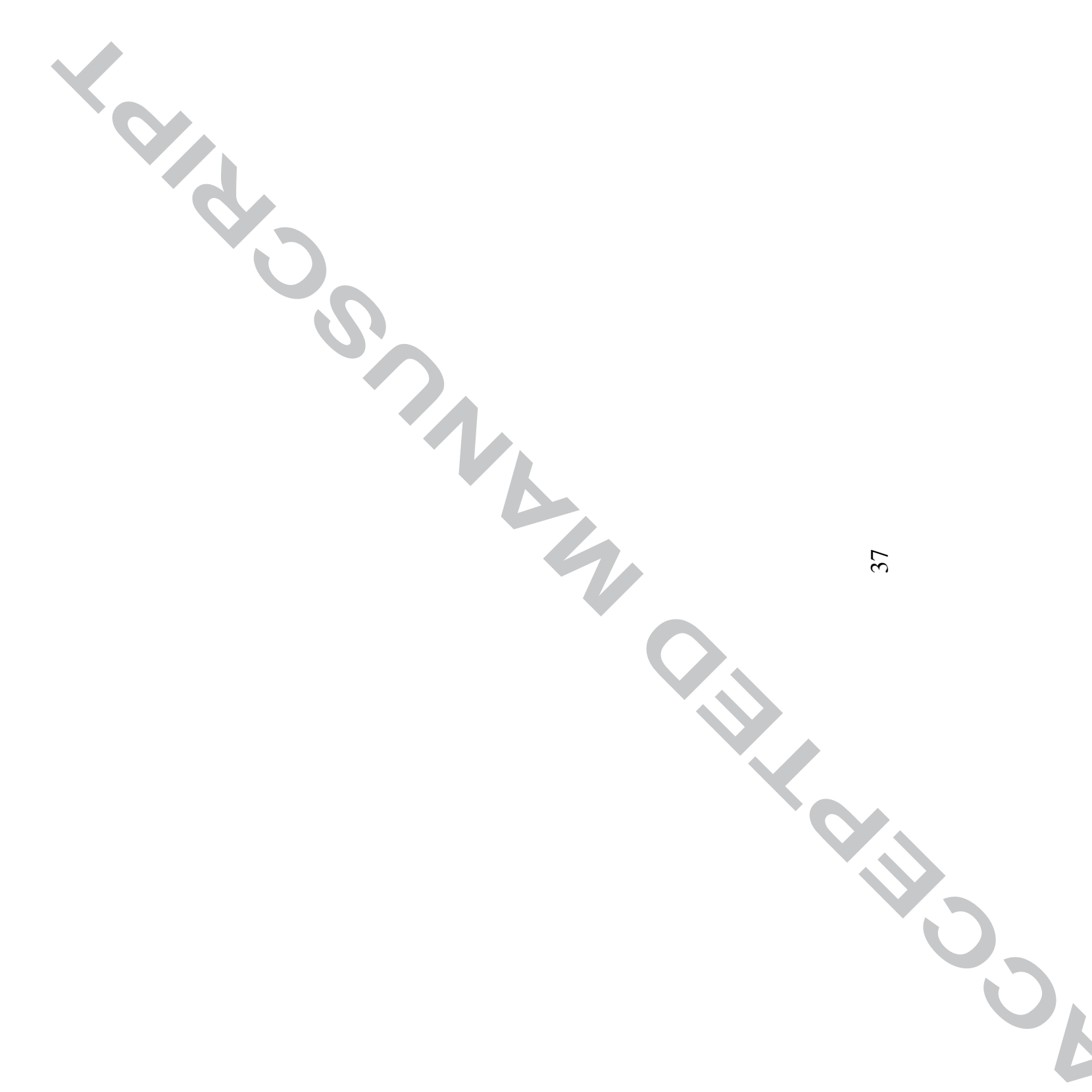




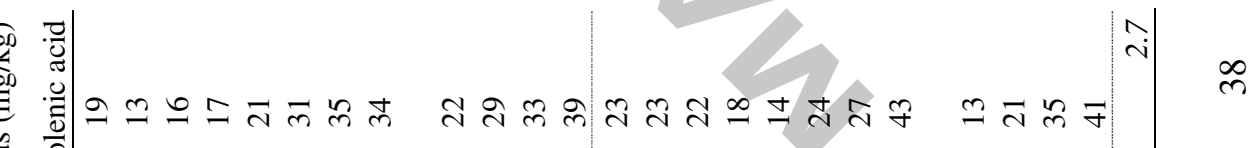

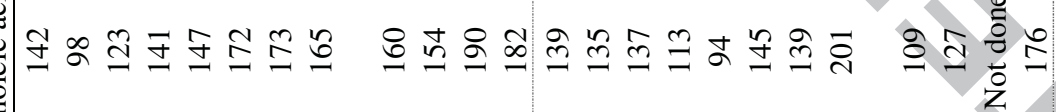
:

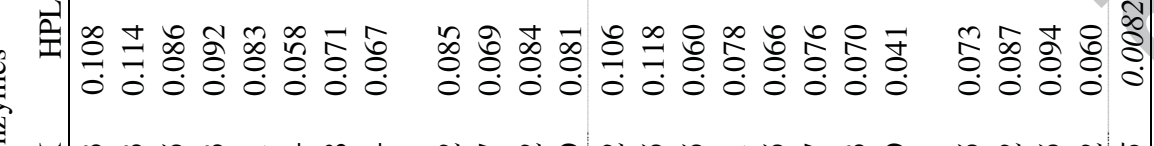

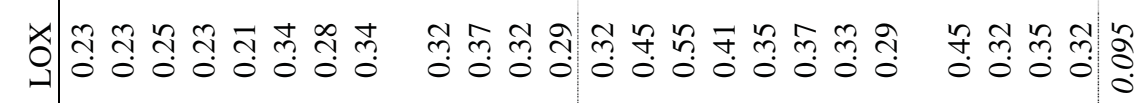

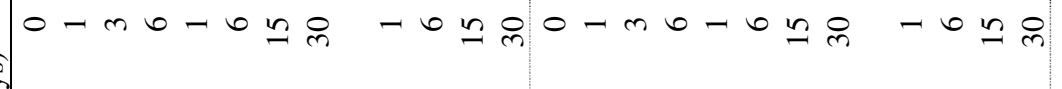

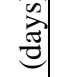

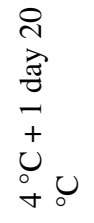

$\begin{array}{lll}2 & & 2 \\ 0 & 0 \\ 0 & 0\end{array}$

U્త 
Renard et al.

Tomato storage

Fig. 1

Firmness (N)

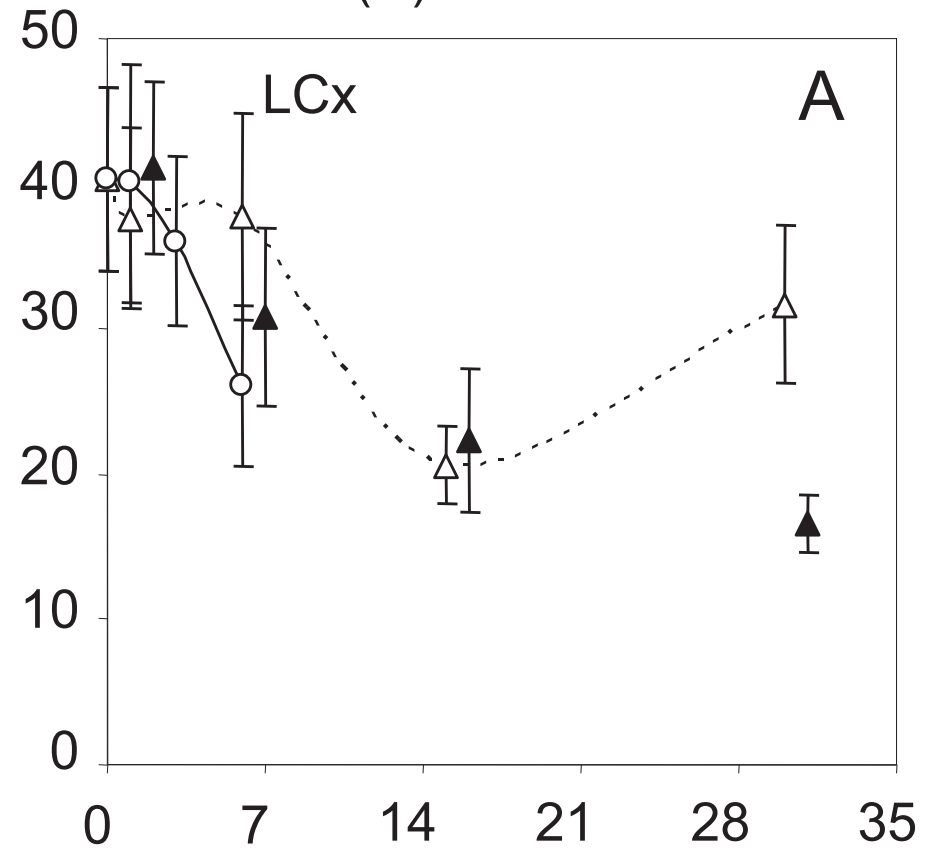

Days after harvest

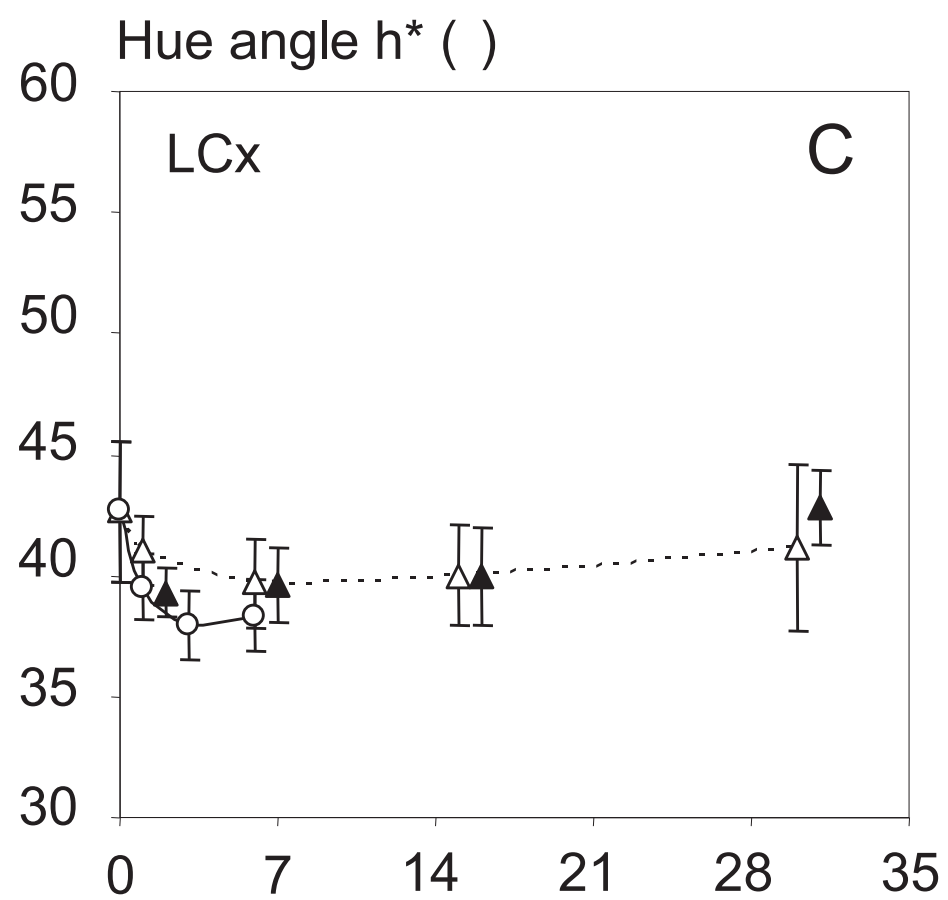

Days after harvest
Firmness (N)

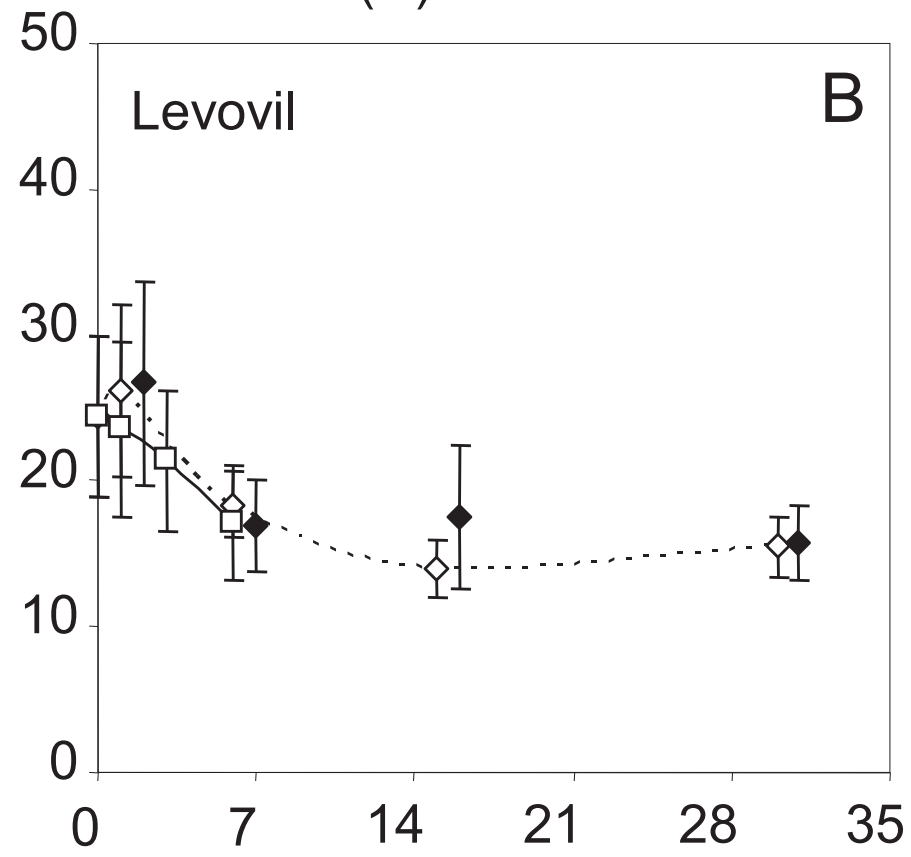

Days after harvest

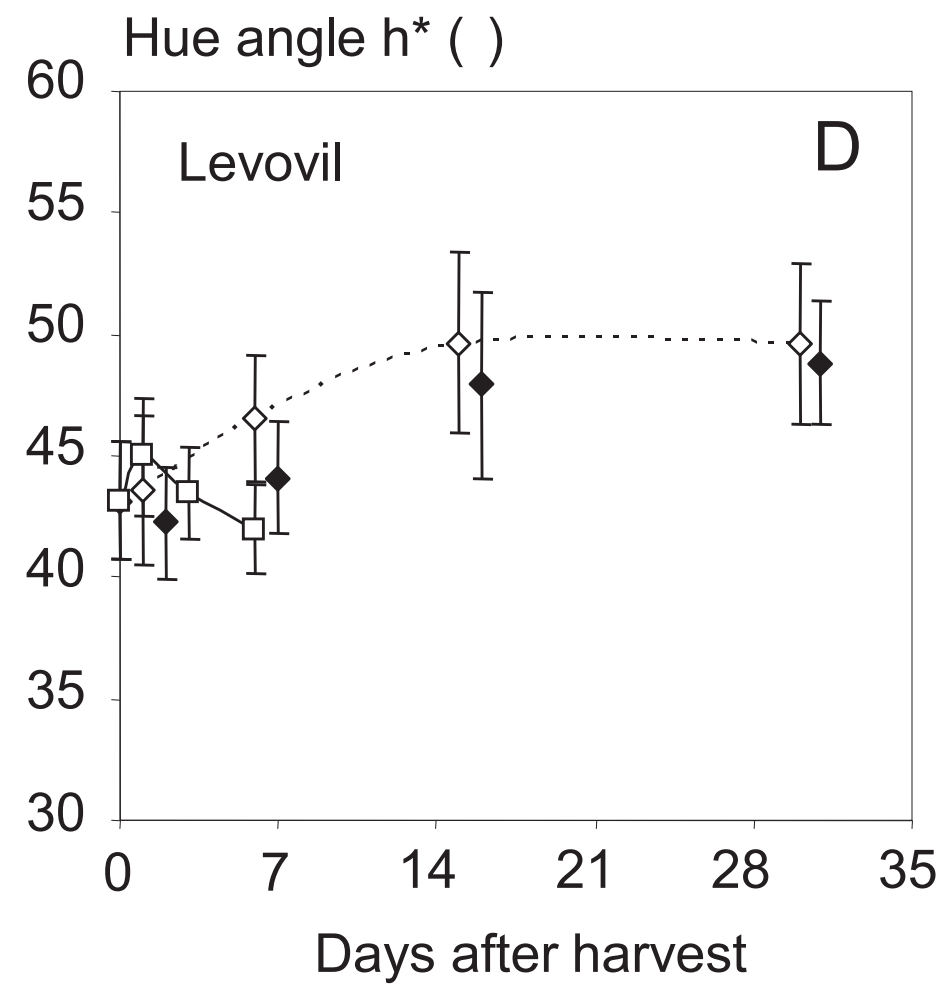


Renard et al.

\section{Tomato storage}

Fig. 2
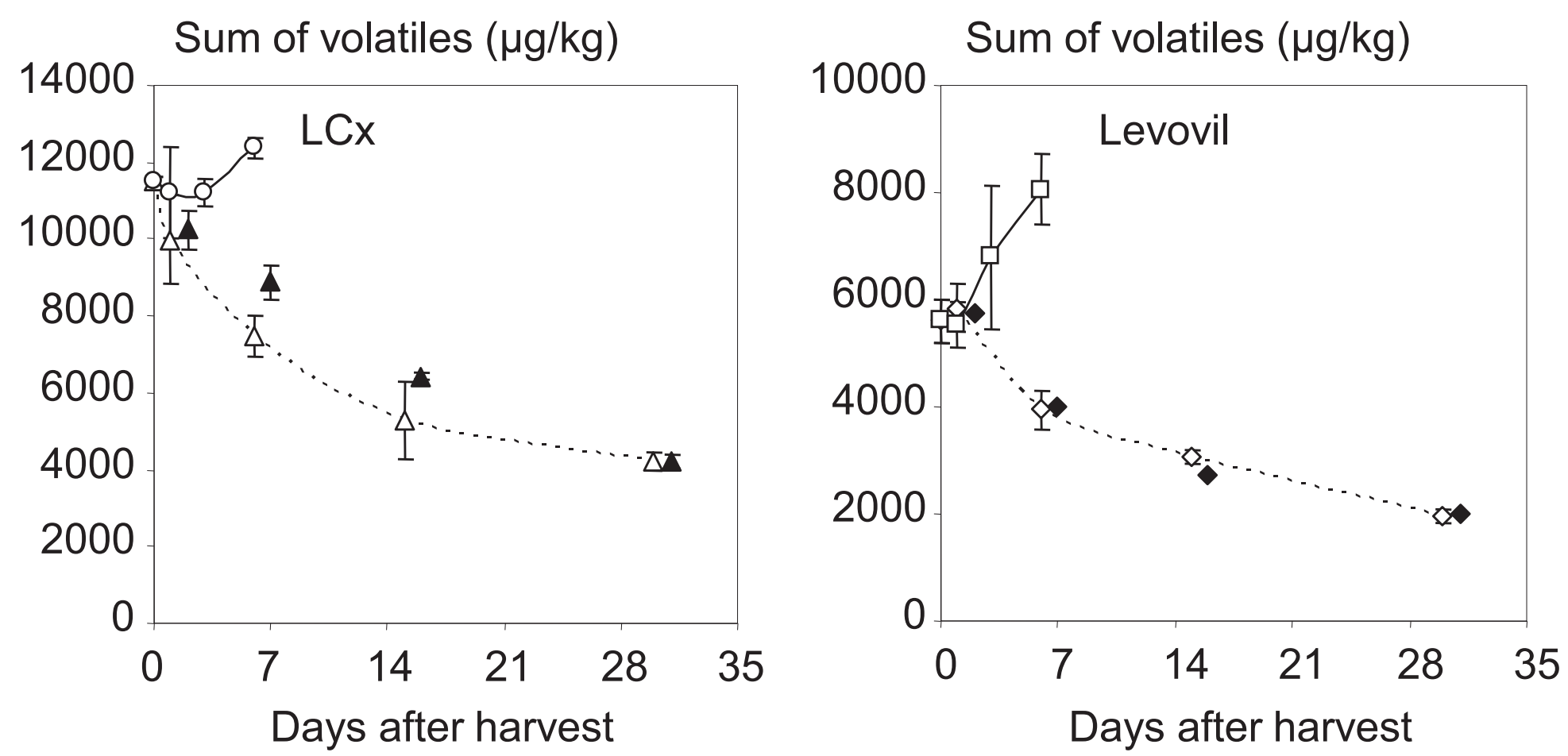
Renard et al.

Tomato storage

Fig. 3
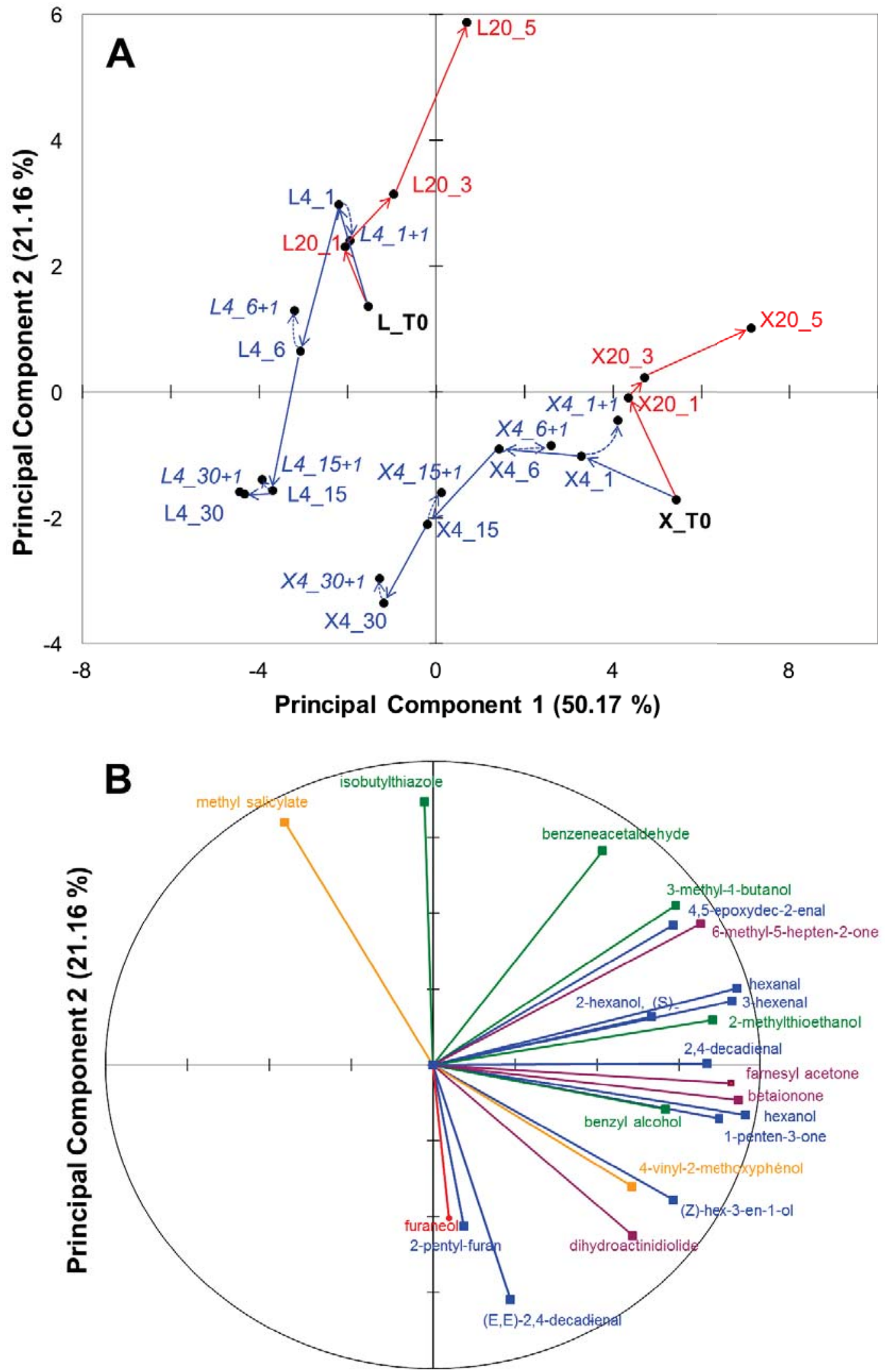

Principal Component 1 (50.17\%) 


\section{Highlights}

- We study evolution of volatiles in two contrasted tomato lines at $20^{\circ} \mathrm{C}$ and $4^{\circ} \mathrm{C}$

- Storage at $4^{\circ} \mathrm{C}$ is detrimental for volatile production and hence aroma

- Volatile levels are not restored by one day at $20^{\circ} \mathrm{C}$

- Storage at $20^{\circ} \mathrm{C}$ up to 1 week leads to increased volatiles, with acceptable texture loss

- This information should be taken up in consumer's information 